\title{
Dog behaviour
}

Intricate picture of genetics, epigenetics, and human-dog relations

Ann-Sofie Sundman

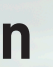


Linköping Studies in Science and Technology

Dissertation No. 1989

\section{Dog behaviour \\ Intricate picture of genetics, epigenetics, and human-dog relations}

Ann-Sofie Sundman

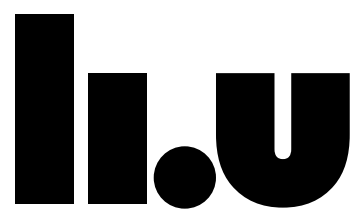

LINKÖPING UNIVERSITY

Department of Physics, Chemistry and Biology

Linköping University, Sweden

Linköping 2019 
Dog behaviour: Intricate picture of genetics, epigenetics, and human-dog relations

(c)Ann-Sofie Sundman, 2019

Cover: Me and my dogs

Photo by Leona Örtenberg

Published articles have been reprinted with the permission of the copyright holder.

Printed in Sweden by LiU-Tryck, Linköping, Sweden, 2019

ISBN: 978-91-7685-072-5

ISSN: 0345-7524 
Haru hunni bunni hunn?

Till mormor, vad tokigt det kan bli 



\section{Abstract}

Dogs, Canis familiaris, share the lives of humans all over the world. That dogs, and the behaviour of dogs, are of interest to many is therefore no surprise. In this thesis, the main aim has been to identify factors that affect dogs' behaviours.

The dog, Canis familiaris, is our first domesticated animal. Since domestication, various types of dogs have developed through adaptation to an environment shared with humans and through our selective breeding, resulting in a unique variation in morphology and behaviour. Although there is an individual variation in the behaviour of dogs, there is also a difference between breeds. Moreover, selection during the last decades has split some breeds into divergent types. Labrador and golden retrievers are divided into a common type, for show and companionship, and a field type, for hunting. By comparing the breed types, we can study the effects of recent selection. In Paper I, we investigate differences in general behavioural traits between Labrador and golden retriever and between common and field type within the two breeds by using results from the standardized behaviour test Dog Mentality Assessment. There were differences between breeds and types for all behavioural traits. However, there was also an interaction between breed and type. Thus, a common/field-type Labrador does not behave like a common/field-type golden retriever. Even though they have been selected for similar traits, the selection has affected the general behavioural traits differently in the two breeds.

In paper II, we were interested in dogs' human-directed social skills. Dogs have a high social competence when it comes to humans. Two experiments commonly used to study these skills are the problem-solving test, where dogs' human-directed behaviours when faced with a problem are measured, and the pointing test, where dogs are tested on how well they understand human gestures. We compared the social skills of German shepherds and Labrador retrievers, and of common- and field-type Labradors. Labradors were more successful in the pointing test and German shepherds stayed closer to their owners during the problem solving. Among Labrador types, the field type had more human eye contact than the common type. Importantly, when comparing the two experiments, we found no positive correlations between the problem-solving test and the pointing test, suggesting that the two tests measure different aspects of human-directed social behaviour in dogs.

A previous study has identified two suggestive genetic regions for human-directed social behaviours during the problem-solving test in beagles. In paper III, we show that these SNPs are also associated to social behaviours in Labrador and golden retrievers. Moreover, the Labrador breed types differed significantly in allele frequencies. This indicates that the two SNPs have been affected by recent selection and may have a part in the differences in sociability between common and field type.

The behaviour of dogs cannot simply be explained by genetics, there is also an environmental component. In paper IV, we study which factors that affect long-term stress in dogs. Long-term cortisol can be measured by hair samples. We found a clear synchronization in hair cortisol concentrations between dogs and their owners. Neither dogs' activity levels nor their behavioural traits affected the cortisol, however, the personality of the owners did. Therefore, we suggest that dogs mirror the stress level of their owners.

The mediator between genes and the environment is epigenetics, and one epigenetic factor is DNA methylation. In paper $\mathbf{V}$, we compared methylation patterns of wolves and dogs as well as dog breeds. Between both wolves and dogs and among dogs there were substantial differences in methylated DNA regions, suggesting that DNA methylation is likely to contribute to the vast variation among canines. We hypothesize that epigenetic factors have been important during domestication and in breed formation.

In this thesis, I cover several aspects on how dogs' behaviours can be affected, and paint an intricate picture on how genetics, epigenetics, and human-dog relations forms dog behaviour. 



\section{Populärvetenskaplig sammanfattning}

Varför gör hunden som den gör? Det är en fråga som kan få ett mycket långt svar. I den här avhandlingen har jag undersökt vad som påverkar beteendet hos våra hundar. Jag har undersökt skillnader i beteende mellan raser och mellan rastyper, tittat närmare på den genetiska grunden till beteenden och vad för miljöaspekter som påverkar våra hundar. Jag har också studerat skillnader i epigenetiska faktorer mellan varg och hund och mellan hundraser.

Hunden är den första arten som domesticerades och detta skedde för mer än 15000 år sedan. Under domesticeringsprocessen och in i nutid har vi människor valt ut de individer som har de önskvärda egenskaper som vi uppskattar och avlat vidare på dessa (selektion). Det har gett upphov till ett antal olika hundtyper och under de tvåhundra senaste åren har många hundraser med stängda stamböcker uppkommit. Inom vissa raser har aveln under de senaste årtiondena dessutom gett upphov till typer inom raserna. Det kan vi till exempel se hos de två retrieverraserna labrador och golden. Det finns en typ som har avlats för utställning och sällskap, den vanliga typen, och en som avlats för sina jaktegenskaper, jakttypen.

I artikel I visar vi att det finns skillnader i de beteendeegenskaper som testas i ett standardiserat beteendetest mellan labrador och golden och mellan den vanliga typen och jakttypen. Skillnaderna är dock inte desamma inom de två raserna mellan typerna. Jaktlabradoren beter sig alltså inte som en jaktgolden och en labrador av vanlig typ beter sig inte som en golden av vanlig typ. Detta till trots att de selekterats för motsvarande egenskaper under de senaste årtiondena. I artikel II jämförs hundraserna schäfer och labrador (och labradortyperna) i hur väl de kommunicerar med människan. Hundar har en exceptionell förmåga att kommunicera med oss. De tar till exempel hjälp av oss när de stöter på problem och kan läsa av vårt kroppsspråk för att hitta godis. Men det finns också en variation mellan hundar. Vi fann att labradorer söker mer ögonkontakt under problemlösningen medan schäfrar är mer passiva och spenderar mer tid nära sin ägare. Under pektestet presterade båda raserna bättre än slumpen men labradorerna var snäppet bättre på att följa pekgesterna. Vi undersökte också om det finns något samband mellan att söka människans kontakt under problemlösningen och förmågan att läsa av människans gester vid pektestet. Det finns det inte utan hundarnas sociala förmåga är mångfacetterad.

Både gener och miljö spelar in när hundars beteende formas. De beteenden som hundar visar upp under problemlösningen har en hög arvbarhet och det har hittats 
två områden i DNA:t hos beaglar som verkar påverka dessa beteenden. I artikel 3 visar vi att dessa områden även påverkar beteendet hos labrador och golden. Vi visar också en skillnad mellan labradorertyperna i vilka genvarianter de har och vi vet därför att aveln har påverkat dessa varianter.

I artikel 4 intresserade vi oss istället för vilka miljöaspekter som påverkar hundarnas beteende. Fokus var hundarnas stressnivåer över tid, vilka kan mätas via kortisol som lagrats in i håret. Vi visar att hundar speglar sin ägares stressnivå och en ägare med höga nivåer av stresshormon har hundar med höga nivåer av stresshormon. Det visade sig också att ägarens personlighetsdrag har en inverkan på hundarnas stressnivåer.

I artikel 5 har vi studerat epigenetiska skillnader mellan olika hundgrupper.

Epigenetik handlar om hur genernas aktivitet regleras, till exempel utifrån miljö, utan att DNA-sekvensen förändras. En epigenetisk faktor är DNA-metylering. Vi har jämfört de generella metyleringsprofilerna hos varg och hund samt olika hundraser och vi kan konstatera att det finns stora skillnader. Epigenetikiska faktorer kan därmed ha en bidragande orsak till den stora variation som finns inom arten hund.

Dessa fem artiklar visar alltså att våra hundars beteende påverkas av selektion, gener och den miljö de lever i (dvs. ägaren de delar livet med), samt att epigenetiska faktorer nog har en inverkan på den stora variationen. 


\section{Papers included in this thesis}

Papers will be referred to by their Roman numerals.

\section{Paper I}

Ann-Sofie Sundman, Martin Johnsson, Dominic Wright, and Per Jensen, 2016. Similar recent selection criteria associated with different behavioural effects in two dog breeds. Genes, Brain and Behavior, 15(8), pp.750-756.

http://doi.org/10.1111/gbb.12317

\section{Paper II}

Ann-Sofie Sundman, Mia E. Persson, Anna Grozelier, Lise-Lotte Halldén, Per Jensen, and Lina S.V. Roth, 2018. Understanding of human referential gestures is not correlated to human-directed social behaviour in Labrador retrievers and German shepherd dogs. Applied Animal Behaviour Science, 201, pp.46-53.

http://doi.org/10.1016/j.applanim.2017.12.017

\section{Paper III}

Mia E. Persson*, Ann-Sofie Sundman*, Lise-Lotte Halldén, Agaia J. Trottier, and Per Jensen, 2018. Sociality genes are associated with human-directed social behaviour in golden and Labrador retriever dogs. PeerJ, 6, p.e5889.

http://doi.org/10.7717/peerj.5889

*Equal contribution

\section{Paper IV}

Ann-Sofie Sundman, Enya Van Poucke, Ann-Charlotte Svensson-Holm, Åshild Faresjö, Elvar Theodorsson, Per Jensen, and Lina S.V. Roth, 2019. Long-term stress levels are synchronized in dogs and their owners. Submitted manuscript.

\section{Paper V}

Ann-Sofie Sundman, Fàbio Pértille, Carlos Guerrero-Bosagna, Luiz Lehmann Coutinho, Elena Jazin, and Per Jensen, 2019. DNA methylation in canine brains is related to domestication and dog-breed formation. Manuscript.

\section{Contribution}

Paper I: Conceived and designed the experiment, gathered data, analysed the data, authored the paper; in collaboration with co-authors

Papers II-V: Conceived and designed the experiments, performed the experiments, analysed the data, authored the paper; in collaboration with co-authors 



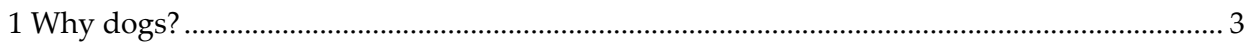

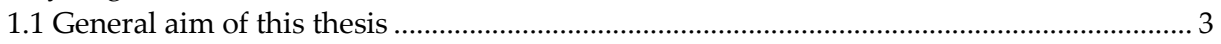

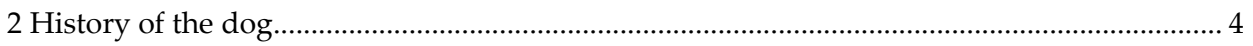

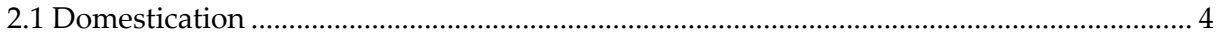

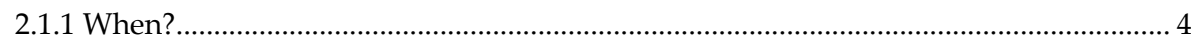

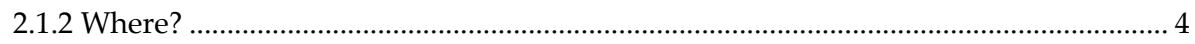

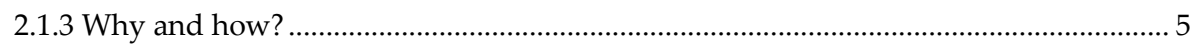

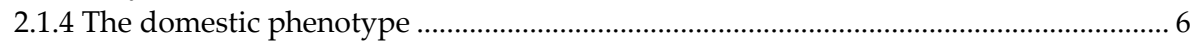

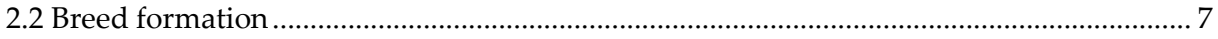

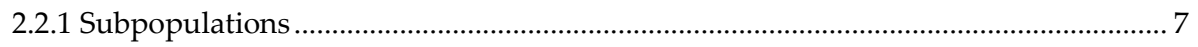

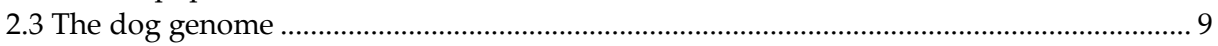

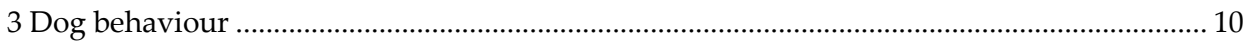

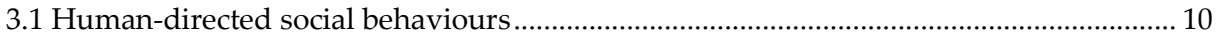

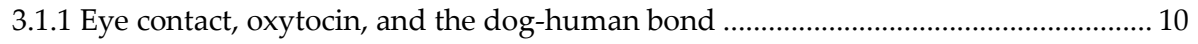

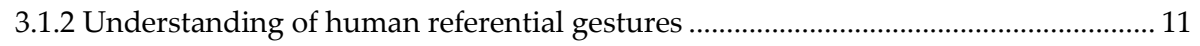

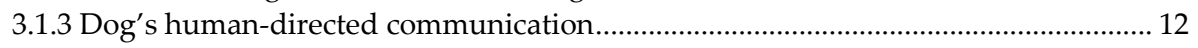

3.1.4 Comparison of human-dog and dog-human communication..................................... 13

3.1.5 Human-directed social competence, a domestication effect? ..................................... 14

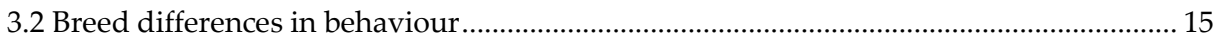

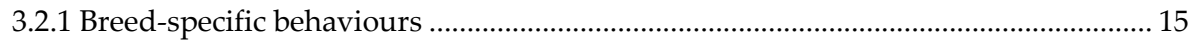

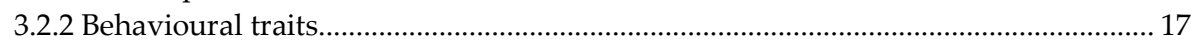

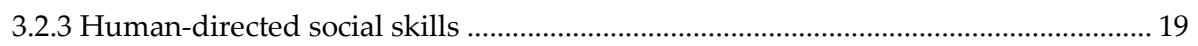

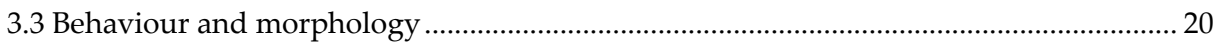

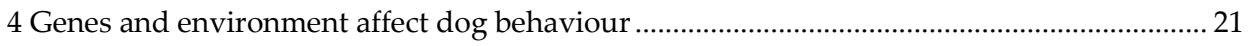

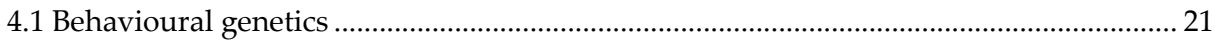

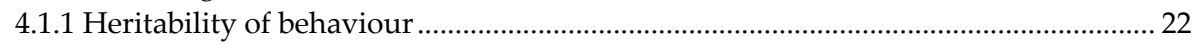

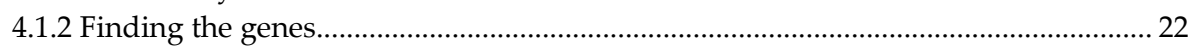

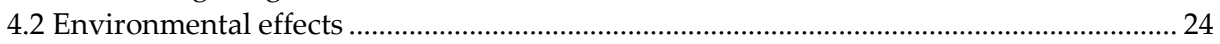

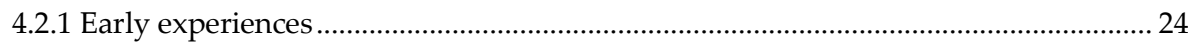

4.2.2 Environmental effects on human-directed social behaviours ....................................... 25

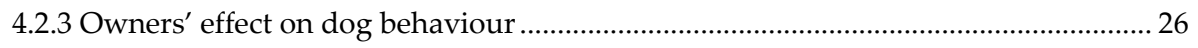

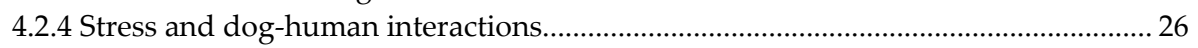

4.2.5 Are we measuring effects of life-history or differences between genetic isolates? .. 28

4.3 Epigenetics - the mediator between environment and genes........................................... 29

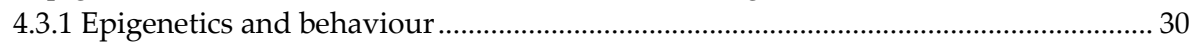

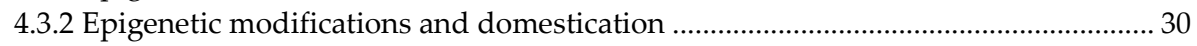

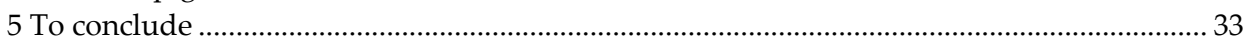

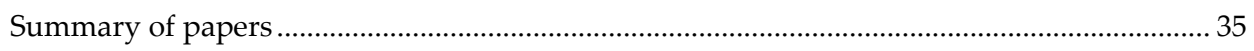

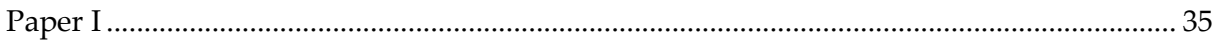

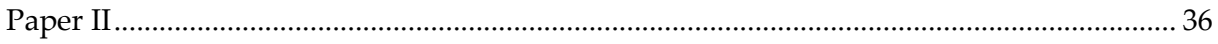

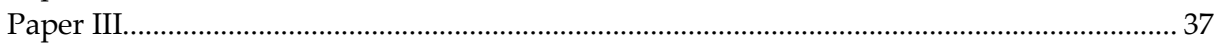

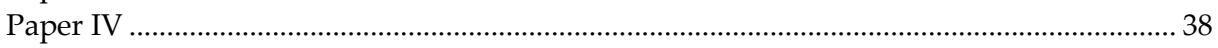

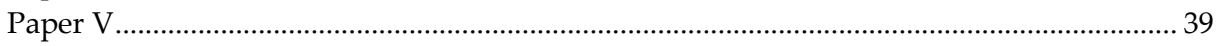

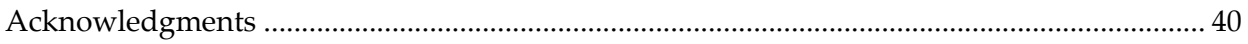

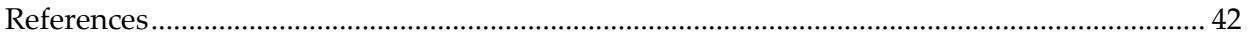




\section{Why dogs?}

The dog, Canis familiaris, was the first species to be domesticated. Today, dogs are a natural part of human society and can be found wherever in the world there are humans. Both behaviourally and morphologically, dogs show an impressive variation and is one of the most variable species in the world. There are many breeds of dogs, with forms and behaviours to suit people of different lifestyles and for a variety of tasks. They are highly appreciated as a companion pet and for their hunting, herding and guarding abilities, just to mention but a few of their abilities. They also have an important role within police, military, and search and rescue, and are invaluable to many as service dogs.

Being the popular and commonly found animal that they are, together with their importance as a model animal, dogs have a high research value. There is an interest to learn more about the behaviour of dogs, and this is of importance to both pet owners, dog trainers and researchers, and, of course, to the dogs themselves from a welfare perspective.

The dog did not start to interest ethologists until rather recently. Focus in the beginning was instead on the behavioural ecology of wild animals. During the first decades of the 20th century, those that used dogs in research were psychologists who were interested in the process of learning. In the middle of the 20th century, one of the first, and to date one of the most extensive, studies on dog behaviour started, namely Scott and Fuller's 20-year-long project. They studied behavioural patterns, breed differences, developmental stages, and genetics of behaviour, an important ground work for researchers (1). From this point on, studies on dog behaviour became increasingly popular. Especially during the last 20 years, studies on, for example, dogs' personality, social cognition, and behavioural genetics have increased greatly (e.g. 2, 3, 4).

\subsection{General aim of this thesis}

The behaviour of dogs varies both on a group level and on an individual level. In this thesis, my aim has been to study which factors affect and contribute to behavioural variation in dogs. I have investigated the behavioural differences between breeds to understand the selection of behaviour, the genetic effects on dogs' behaviour, and the owners' effects on dog behaviour. I have also studied epigenetic differences between wolf and dogs, as well as differences across dog breeds. 


\section{History of the dog}

The dog has been formed through domestication, morphologically as well as behaviourally. To understand dogs' behaviour, the variation within the dog, and dogs' importance to humans, we need to start from the beginning.

\subsection{Domestication}

Several species have been domesticated, but the dog was the first by several thousand years. Domestication is the process where a population of animals, or plants, through genetic changes is adapted to life with humans. Studying domestication processes will also increase our knowledge about evolutionary processes.

While Darwin (1868) expressed about the dogs' ancestor(s) that "[w]e shall probably never be able to ascertain their origin with certainty" (5), today we do know that the grey wolf, and only the wolf, is the ancestor of the dog (6-8). The questions of when, where, why, and how the dog was domesticated, however, remain subjects of scientific debate.

\subsubsection{When?}

Due to several bottlenecks and admixtures between dogs and wolves and between dog lineages, it is not an easy task to find neither time point nor geographical location for domestication. According to archaeological findings, the domesticated dog existed 15,000 years ago. Skeletal remains from this time are clearly distinguishable from those of wolves (9). Early molecular work suggests a divergence between wolves and dogs long before that, over 100,000 years ago (8). However, more recent studies are in congruence with archaeological data and suggest domestication to have taken place closer to 15,000 years ago (10-13), although between 20,000-40,000 years has also been indicated $(14,15)$.

\subsubsection{Where?}

Several geographical locations for the origin of dogs have been pointed out. Basically, these locations are based on where the highest genetic diversity can be found, which is an indication of closeness to the origin. However, the results vary according to method, which wolves and dogs that are included, and whether DNA 
from ancient samples are taken into account. Places of origin that have been suggested are Southeast Asia $(10,11,16)$, the Middle East (17), and Europe $(14,18)$. Most studies suggest a single domestication event, whereas Frantz, et al. (19) hypothesized that dogs were domesticated twice: once in Southeast Asia and once in Europe.

As the techniques for using ancient DNA are increasingly more robust, and dense genotyping increasingly faster and less expensive, new discoveries to the when and where of the dog's origin are likely to occur.

\subsubsection{Why and how?}

As to the why and how, it is generally accepted that the dog's ancestors entered domestication through a commensal route that started by them taking advantage of human wastes. Wolves are opportunistic scavengers and it is believed that less fearful wolves were drawn to the refuse of the human encampments, hereby finding a new niche where they habituated to humans $(20,21)$. Thus, at least initially, the domestication process of wolves into dogs was not deliberate or conceived by human hunters and gatherers, but based on natural selection, a process called the selfdomestication hypothesis (22). It is hypothesized, however, that that humans in the beginning inadvertently selected the most adjustable wolves by dispelling or dispatching wolves that did not conform to human societal rules $(21,23)$. The Russian geneticist Dmitry Belyaev even wrote that "[i]t is obvious that selection for behavior has been unconsciously carried out by man since the earliest stages of animal domestication" based on the fact that contact with humans as well as obeying them and reproducing in their care are prerequisites for domestication (24).

At some point the commensal relationship between the two species developed into a mutual relationship where both parties benefited from the association and, eventually, intentional breeding for desired traits (20). Dogs, or rather proto-dogs, got food and protection from their human partners who in return probably used the dogs for, among other things, guarding, support during scavenging and hunting, and for food and pelts. What is believed to be one of the earliest documentation of dogs are cave paintings in Saudi Arabia, dated to 9,000-10,000 years ago, depicting humans and dogs hunting together (25). Interestingly, already at the beginning of our partnership, dogs seem to have been important to humans, shown for example by the findings of burial sites where dogs were buried and site in Israel dated to $11,000-12,000$ years ago where an elderly person was buried together with a puppy (26). 


\subsubsection{The domestic phenotype}

The early archaeological records find that dogs' skulls and teeth show a general reduction in size, and especially a shortening and widening of the muzzle and snout compared to wolves (27). These characteristics are in concurrence with what is called 'the domestic phenotype'. Indeed, compared to their wild ancestor, domesticated animals have several traits in common. Morphological differences include changes in body size, body proportions (e.g. brachycephalia and chondrodystrophia), brain size, and coat colour alteration, specifically an increase of white colouration. Domesticated animals also show altered physiological traits, they for example differ in endocrine responses and reproductive cycles. More specifically, domestic animals become sexually mature earlier, have a shorter generation time, and have larger litters. Of course, there is also a difference in behaviour between wild and domestic counterparts, where the latter show a decrease in wariness of humans but also a lower general fear, lower reactivity, and an increased sociability (20, 27-29).

These effects have also been found in experimental settings. In a famous experiment by geneticist Dmitry Belyaev, farmed silver foxes were bred for tameness (24). Even though tameness was the only trait that was selected for, in few generations the selected foxes showed other characteristics not found in the control population. These changes included coat depigmentation (white marks), floppy ears, curled tails, and alterations in reproductive pattern. Further into the selection the foxes showed even more changes, for example reduction in both body size and relative brain size, and altered body proportions $(24,30)$. Similar selection experiments in other species have also shown changes in concurrence with the domestic phenotype, for example in chickens (29) and rats (31).

Hence, even though the initial part of the domestication process was not directed by focused artificial selection, solely a reduced fear of humans would predict phenotypic changes. This happens through a correlated selection response. Even if selection only targets few genes, these may lead to a cascade of effects through genetic mechanisms such as pleiotropy, epistasis, and linkage (29). Belyaev (24) suggested that the domestication effects may be due to changes in gene regulation rather than genetic structure, and a recent hypothesis suggests that the domestic phenotype is caused by deficiencies of neural crest cells during embryogenesis (32). It is also reasonable that epigenetic mechanisms have had an important part during animal domestication. These can occur in direct response to environmental changes by modifying gene expression without changing the genome (29). 


\subsection{Breed formation}

Since domestication, various types of dogs have developed through adaptation to an environment shared with humans and through selective breeding. This has resulted in a unique within-species variation in morphology and behaviour between breeds. Today, the international kennel organization Fédération Cynologique Internationale (FCI) recognizes 346 breeds (www.fci.be), but there are likely more than 400 breeds around the world.

Early depictions and archaeological evidence suggest that morphologically different dogs have existed for a long time. An excavation in Sværdborg, Denmark, of an 8000year-old site identified three differently sized dog types, and remains from ancient Egypt, 4000 years ago, show that dogs similar to mastiffs and greyhounds existed at that time $(9,33)$. Interestingly though, the breeding practise of today, with stringent selective breeding, closed stud books, and breed standards with focus on form rather than function, is a quite recent invention that has its origin in the 19th century Victorian era (years 1837-1901) (34). Genetic comparisons of breeds have failed to find unique mitochondrial DNA (maternal inheritance) and $Y$ chromosome haplotypes (paternal inheritance) within breeds, indicating that breeds have not been isolated for a long period of time (33). In a study on the origin of breeds, Parker, et al. (35) estimated, based on haplotype sharing, when breeds were created and the results indicate that most breeds were, in fact, created less than 200 years ago.

The to date largest phylogenetic analysis of the relationship between breeds identified 23 clades for 150 different breeds (35). It was found that while haplotype sharing is common among breeds within clades, sharing across clades is less frequent. Thus, it seems that clades represent breed prototypes that existed before modern breeding practises began and that modern breeds were created via selection within the prototypes (35).

\subsubsection{Subpopulations}

Although there is a great homogeneity within dog breeds, substructures exist due to geography and different selection aims among breeders. There is, for example, a high genetic diversity between golden retriever populations in Europe and North America due to a low degree of genetic flow between the two (36). There are also breeds where a divergence has occurred because breeders have fundamentally different selection criteria, creating different selection lines (breed types) within the breeds. Commonly, this split occurs when there are those that breed for form (dog shows), 
modern function (dog sports and pet), or original function. To exemplify, in the herding breeds border collie and kelpie there is a clear diversification between those bred strictly for herding and those bred for show and sports $(36,37)$. In the kelpie, this has resulted in a separation of the types into two different breeds, Australian kelpie and Australian stock dog/working kelpie. A similar split has taken place in some of the spaniels and retrievers. In both golden and Labrador retriever, for instance, there are two types: one where selection focuses on traits coupled to show and companionability (common type), and one where selection focuses on functionality as gundogs, their original function (field type) (Paper I, II, III). See Fig. 1 for pictures of the different types of the two breeds.

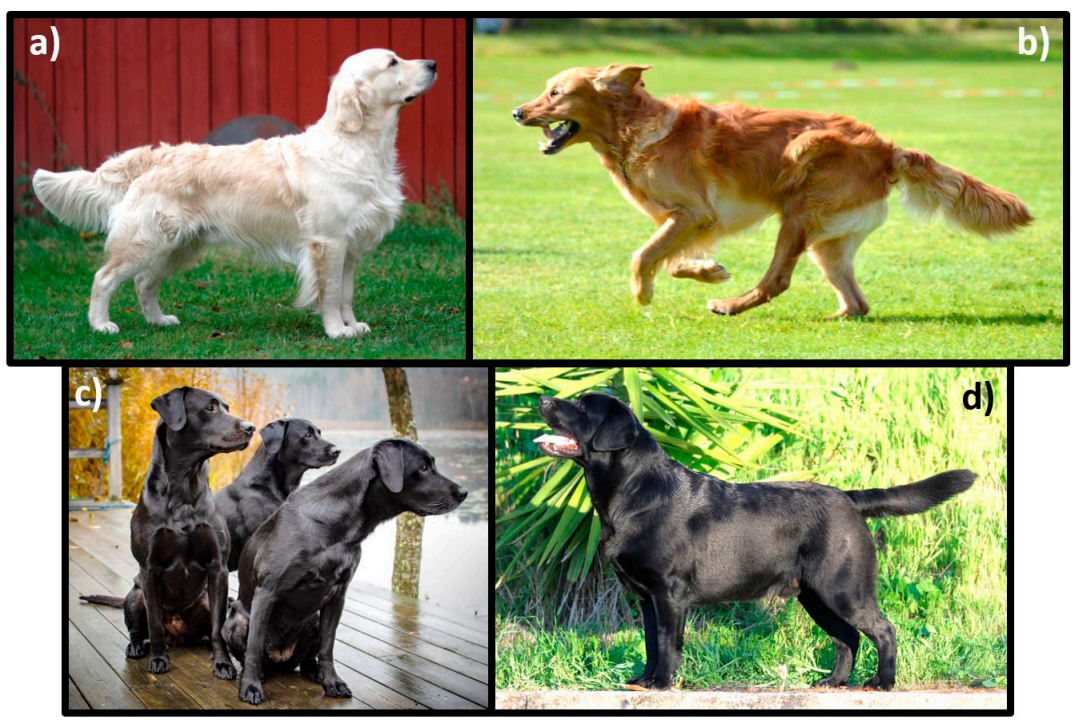

Figure 1. Pictures of golden ( $a$ and $b$ ) and Labrador retrievers (c and d) of the two subpopulations common (a and d) and field type (b and c).

Photo credits:

a) By Golden Retriever Raseåd, CC BY-SA 4.0, commons.wikimedia.org/w/index.php?curid $=67193872$

b) Amanda Dahlin, published with permission c) CC0

d) By Giuseppe Pitzus, CC BY-SA 4.0, commons.wikimedia.org/w/index.php?curid=58821150 


\subsection{The dog genome}

Domestication and breed formation have formed not only morphology and behaviour, but of course also dog's genome.

During the last 200 years, an intense selection process has taken place, creating the different breeds. Many breeds were created through a small number of founders, a small population size, and high levels of inbreeding. Additionally, as a breed was established, admixture with other breeds has been strictly limited. This breeding practise has caused genetic variation between breeds whereas variation within breeds is very low. Purebred dogs can, for example, be assigned to the correct breed based solely on genotype $(17,34)$. The breeding has also caused a high linkage disequilibrium in the dog genome where long-range haplotype blocks are inherited together. This makes it possible for genome-wide analyses using relatively few SNPs (single nucleotide polymorphisms). Compared to the human genome, haplotype blocks in the dog genome are about 50 times longer and, therefore, a genome-wide analysis in dogs requires only a fraction of the SNPs needed in humans $(4,38)$.

Because of their genetic makeup, dogs are a suitable model for genetic studies. Accordingly, the dog genome was one of the first to be sequenced (38). Taking advantage of breed differences in both phenotypic traits and genetics, genes underlying both Mendelian and complex diseases have been identified in dogs, many with human analogies (39). Also, genes have been found for morphological traits such as size (40), colour (41), and coat type (42). Actually, only three genes are responsible for the majority of coat-type variation found in breeds: FGF5 for long or short, KRT71 for straight or curly, and RSPO2 for smooth or wired (42). With the strong selective breeding that we see in dog breeds, this genetic architecture is expected, where few genes have large effects. 


\section{Dog behaviour}

The domestication process and adaptations to a human-dominated niche has formed the behaviour of the modern dog. Low fear of and low aggression towards humans was necessary for domestication, but dogs have traits beyond this that make them successful in the human world, especially their extreme sociability. Furthermore, selection for various functions for different groups of dogs has further formed and differentiated dogs' behaviour.

\subsection{Human-directed social behaviours}

It can be argued that dogs' natural ecological niche is the anthropogenic environment, and that they are well adapted to it. Human-directed sociability is an important trait in our dogs, and during evolution alongside humans, dogs seem to have acquired an interspecific social competence. Their abilities to communicate, to cooperate, and to form strong social attachments to humans are examples of this (43).

\subsubsection{Eye contact, oxytocin, and the dog-human bond}

In communication between dog and owner, eye contact is a central part. Both humans and dogs use eye contact in their communication with each other (e.g. 44, 45). In studies of spontaneous eye contact with humans, dogs look more often and for a longer duration than both the wolf (46) and the feral domestic dog, the dingo (47). Actually, already from an age of five weeks, dog puppies seek more human eye contact than wolf puppies (48).

Eye contact is not only important for communication but also for social bonding. Oxytocin is a hormone that facilitates bonding between social partners among both dogs, humans, and other mammals (49). Interestingly, an increase in both the dog and its owner has been observed during interspecific social interactions (50). More specifically, Nagasawa, et al. (46) studied eye contact between dogs and their caregivers and concluded that oxytocin in both dog and human increase during eye contact. By administering oxytocin, it was also shown that an increase in oxytocin elicited more eye contact. Thus, eye contact creates a positive oxytocin loop in both dogs and humans. In comparison, the same phenomenon was not found between wolves and their caregivers (46). 
Indeed, dogs and their owners form a strong social bond. By using the Ainsworth Strange Situation Procedure, developed to study the attachment between a human child and its parents, Topál, et al. (51) concluded that a similar attachment bond exists between dog and owner. Dogs use their owner as a secure base and increase both exploration and playing in their presence. In the absence of their owner they are passive, even with a stranger present. When hand-reared wolf puppies were compared to similarly reared dog puppies, wolves did not show patterns of attachment to their owners whereas dogs did (52).

\subsubsection{Understanding of human referential gestures}

Another focus of study has been dogs' understanding of referential gestures, for example pointing. Pointing is a commonly used referential gesture in humans. It is used across cultures and both practised and understood by infants (53). Studies have shown that dogs readily and reliably use several human referential cues to find hidden food (see 3, for review, eg. 54, 55).

Commonly, animals are tested on their understanding of referential gestures in an object-choice test where a piece of food is hidden in one of two containers. A referential cue is given as to where the treat is located, for example by pointing at it, before the subject is asked to make its choice. The pointing gestures can vary in difficulty from simple cues like tapping the correct container or holding the gesture while the subject is making its choice, to more subtle signals like briefly pointing towards the container from a distance (momentary distal pointing). The cues can also vary such as gazing or head turning, etc. Dogs do not only understand simple signals but also various other ones (3). They primarily use protruding body parts as cues but can easily generalize between different gestures. For instance pointing with a finger, elbow, or foot, and cross-pointing $(56,57)$.

Dogs' understanding of referential gestures cannot be explained by simple local enhancement. This is shown by the facts that dogs choose correctly even when the signaller is standing next to the wrong choice (54), or moves away from the correct container (58), and they fail if a stick is used for pointing (57). Neither do dogs learn during the experiment (eg. Paper II; 59). Even young puppies have been shown to understand momentary distal pointing, and environmental factors seems to have little effect $(59,60)$. Thus, it seems that, to some degree, dogs' skill for understanding human referential gestures is innate. 
Interestingly, although not conclusive, there are results that support the hypothesis that dogs understand the sender's intention to communicate. If the pointing is not preceded by an ostensive cue, i.e. a signal that expresses communicative intent, dogs choose at random $(45,61)$.

Surprisingly, non-human primates, despite being phylogenetically close to humans, have a low comprehension of these gestures and do generally not perform above chance level $(62,63)$. In fact, in a comparative experiment, Kirchhofer, et al. (64) found that dogs outperform chimpanzees. When compared to wolves, dogs' closest relative, they, again, show a better understanding of human communicative gestures (62). With training and intense socialization, wolves can, however, successfully follow human referential cues (65-67). Other species, both domesticated and captive wild species, have been tested in the object-choice paradigm. Dolphins, goats, horses, and cats can use human pointing gestures to find food, but, it does seem that the dog is the most flexible non-human species in this task $(3,68)$.

\subsubsection{Dog's human-directed communication}

Not only do dogs understand human communication, they also communicate with us through, for example, attention-seeking and attention-directing signals. Worsley and O'Hara (69) identified 19 intentional signals used by dogs in their human communication that can be classified as referential gestures (e.g. directed towards an object, aimed at a recipient, and that was understood by a recipient). The situations in which dogs use these signals are primarily contexts when they want something, e.g. petting or food. The most common gesture is gaze alternation between a desired object and a recipient (69).

Gaze alternations and eye contact, specifically, have previously been identified in dogs as referential gestures and as important behaviours for social communication. Dogs readily use this to indicate the location of hidden food (44). Interestingly, dogs indicate the location even more frequently when the owner is not present when the desirable object is hidden, suggesting that dogs intend to inform their owner of the location (70).

Dogs are especially prone to show gaze alternations when faced with a problemsolving situation, for example a piece of food in a closed container. In MarshallPescini, et al. (71) it is shown that dogs perform more gaze alternations when the problem becomes unsolvable compared to solvable, and more gaze alternations in the presence of an attentive person than an inattentive one. These results suggest that 
the gesture is both referential and intentional. Moreover, by using a problem-solving paradigm, dog-human communication and attention seeking is stimulated and can be systematically studied (Paper II, III).

As with the understanding of human referential gestures, dogs and wolves differ in their behaviour during a problem-solving paradigm. Several studies show that wolves do not seek human contact to the same extent as dogs do and that they rarely seek eye contact (e.g. 72). The difference is clear even when comparing wolves to shelter dogs and free-ranging dogs (73-75). Already at nine weeks of age and with a similar upbringing as the dogs they are compared to, this difference can be observed between the species (48). In turn, wolves show a higher persistency in trying to solve the problem at hand $(74,75)$, and this they also do in the absence of humans $(76)$.

It has been argued that social behaviours during the problem-solving test may measure persistency rather than sociability. When including the duration spent interacting with the problem in the statistical model, Marshall-Pescini, et al. (75) found no difference in gazing behaviour between wolves and dogs. Studies also show negative correlations between test interactions and eye contact $(74,75)$. At the same time, in Paper II, it is the group with highest passivity that have the shortest duration of eye contact (i.e. German shepherd dogs), and principal component analyses consistently form a component for test interactions separate from social behaviours (Paper II, 77). It is difficult to disentangle persistent problem solving from sociability in the problem-solving test. Different measurements of duration during the same test may correlate simply because a subject cannot engage in two activities at the same time.

\subsubsection{Comparison of human-dog and dog-human communication}

As we have seen, the pointing test and the problem-solving test are commonly used to study dogs' understanding of human referential gestures and their humandirected social behaviour, respectively. Because of this, in Paper II we wanted to compare dogs' behaviours in the two tests.

Even though the dog as a species systematically differs from other species, there are still differences among dogs. Indeed, in Paper II, only 64 out of the 153 dogs reached individual significance in the pointing test (momentary distal cue), but as a group they performed better than chance (Fig. 2). In this study, the same dogs were tested in both a pointing test and a problem-solving test to be able to compare the two. According to our results, none of the behaviours in the problem-solving test 
positively correlate with performance in the pointing test. Hence, dogs that understand human referential gestures do not themselves engage more in humandirected behaviours than other dogs. A similar result was found by MacLean, et al. (78), where they compared performance in several tests for social cognition. Simply, dogs' social competence is complex and multifaceted.

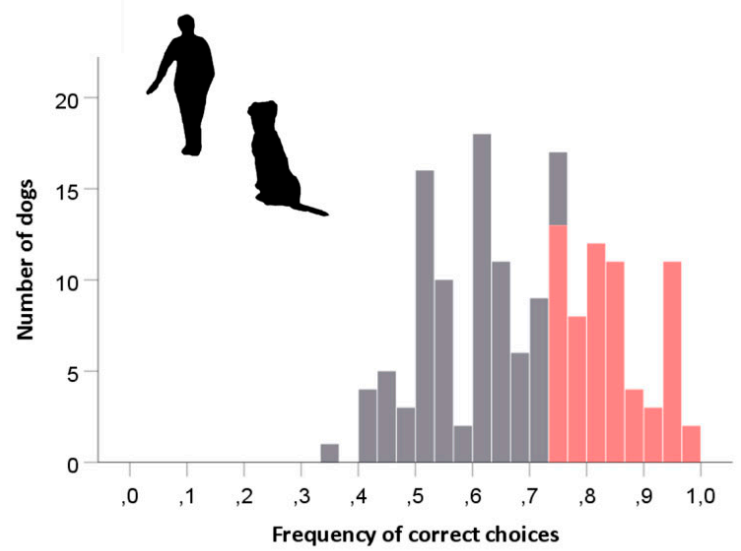

Figure 2. Histogram of performance in the pointing test for all participants (German shepherd and Labrador retriever dogs) in Paper II. Pink bars represent dogs that reached individual significance (binomial $p<0.05$ ). Although not the performance of all individuals can be separated from chance, as a group, dogs understand human pointing.

\subsubsection{Human-directed social competence, a domestication effect?}

As we have seen, comparative studies in human-directed social competence point out differences between both dog and wolf $(62,72)$, and dog and non-human primates $(64,78)$. These differences suggest that dogs have a greater capacity for social competence than the other species. Actually, the social competence of dogs has been argued in some cases to be closer that of human infants than wolves or apes, and developed during a convergent evolution with humans $(78,79)$.

It is compelling that the social competence of dogs has evolved during domestication $(72,80)$. It has been pointed out, though, that there are confounding differences between the environment of dogs and the species it is compared to and that these may be more important than evolutionary history (e.g. 81). Intensely socialised and trained wolves do, for example, show understanding for human referential gestures 
(66), and dog puppies not socialised before the age of about 14 weeks (i.e. during critical period) cannot form normal relationships with people (82).

Nevertheless, the facts, among others, that 1 ) dogs show human-directed social skills already from a young age $(48,60), 2)$ that free-roaming dogs and shelter dogs, presumably with less human interactions during their upbringing, behave as pet dogs in gazing behaviour and differ from wolves (73-75), and 3) the feral dingo behaves intermediately compared to domestic dogs and wolves both in spontaneous eye contact and referential-gesture understanding $(47,83)$, suggest that the social competence of dogs have been affected by domestication.

When discussing the cause of dogs' social skills, we cannot forget the dog's ancestor. Even though dogs may show a larger interspecific social competence, wolves are highly social animals with a rich intraspecific communication and cooperation. It is likely that the social skills of dogs have evolved on this basis (84) and have been further formed during the domestication process. This has given the individual dog a capacity for human social skills that is developed and shaped during ontogeny in the human world (85).

\subsection{Breed differences in behaviour}

A dog is a dog and it behaves as a dog. But, among dogs, we also find a large phenotypic variation in behaviour. Not only is there an individual variation, but there is also variation between breeds and breed clusters both in breed-specific behaviours, more general behavioural traits, and human-directed social behaviours (for review: 86).

\subsubsection{Breed-specific behaviours}

Different groups of dogs have evolved since the beginning of the dog through selection pressures witched focused on required function, such as hunting, herding, and guarding, as well as adaptations to different environments (35). These differences clearly stem from selection for the historical function of the breed groups. Although modern breeds are a new concept, breeds still have their roots in ancient types.

One thing that has been modified in dogs bred for different functions is the predatory motor pattern consisting of the behaviours orient, eye stalk, chase, grab- 
bite, kill-bite, dissect, and consume. For example, sheepdogs possess a hypertrophied orient-eye stalk-chase sequence, retrievers a hypertrophied orient and grab-bite, and livestock guardians a suppression of the whole sequence (Coppinger and Coppinger, 1996; Mehrkam and Wynne, 2014). It would be difficult to train a sighthound to herd, a terrier to retrieve without crushing the game, and a livestock guardian to hunt, in comparison to how it would be to train a sheepdog, a retriever, and a hound for these respective tasks.

However, there is also an individual variation for breed-specific behaviours, for example in herding behaviours for border collies (87). In some breeds this is due to a relaxed selection for breed-specific behaviours when the breed is no longer bred for function. In the common- and field-type Labrador and golden retrievers, this is apparent when studying data from a Swedish assessment of functionality for retrievers developed by the Swedish kennel club. Field-type dogs clearly show a greater interest for retrieving, both dummy and, especially, game (Fig. 3; (88)). Indeed, today there are many dogs that are mainly companion dogs and for these individuals, there is no longer a reason to breed for historical function.

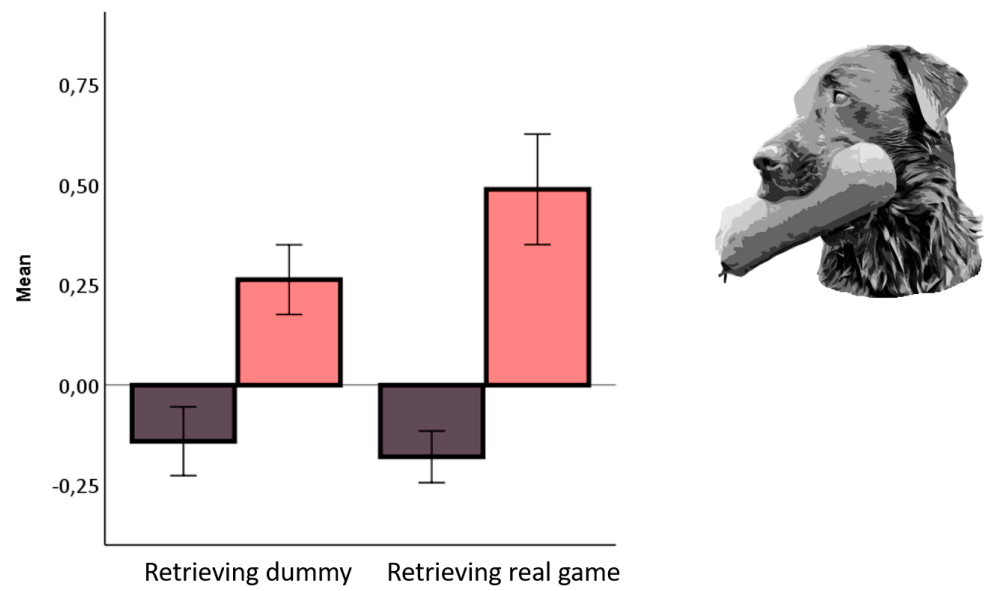

Figure 3. Comparison of the performance of common type (dark) and field type (pink) in an assessment of retrieving abilities in a test developed by the Swedish kennel club (funktionsbeskrivning retriever, FB-R). Higher scores indicate a hunting dog with greater functionality. During a series of subtests, retrievers are tested on their functionality. A principal component on the behavioural reactions found, among others, components for gripping and retrieving a dummy and gripping and retrieving real game (Louise Brodd, Master thesis, 2016 (88)). 


\subsubsection{Behavioural traits}

We can also study more general behavioural traits. While these, too, differ individually (yes, dogs have personality: 89, 90), behaviours also differ on a group level. Breed differences have been reported for several behavioural traits and in several studies (e.g. Paper I, 1, 91, 92).

Differences in behavioural traits between individuals or groups of dogs can be studied through standardised behaviour tests. In Sweden, we have the Dog Mentality Assessment which is a test battery consisting of ten standardised subtests that assess the dog's reaction to, among other things, strangers, play, suddenly appearing dummy, and a sudden loud sound. When correlated, the behaviour reactions represent five or six behavioural traits: curiosity, playfulness, chase interest, sociability (or social curiosity and social greeting), and aggression (Paper I; 93).

The Dog Mentality Assessment was developed and is arranged by the Swedish Working Dog Club, and from its start in 1997, more than 100,000 dogs of various breeds have been tested, and all results are registered by the Swedish Kennel Club. An impressive database that can be used in dog behaviour research. In a series of studies, Svartberg found the Dog Mentality Assessment to be both reliable and valid $(90,93-95)$.

Svartberg (96) found breed differences in the behavioural traits among 31 different breeds. For example, the extremes for the different traits were: playfulness, Malinois (highest) and Swiss mountain dog (lowest); curiosity, Labrador and collie; sociability, flat-coated retriever and Groenendael; aggressiveness, Malinois and Leonberger. In Paper I, we used data from the Dog Mentality Assessment to study how selection affects behaviour. We found that there are differences between the breeds Labrador retriever and golden retriever. Labradors are more curious, playful and aggressive in comparison to goldens that, instead, are more sociable and show higher chase interest.

Behavioural traits of dogs can also be gathered from questionnaires, where the owner, or someone else that knows the dog well, can assess how the dog would react in several described scenarios. Two such questionnaires that have been validated and that are commonly used in research, are the Dog Personality Questionnaire (97) and C-BARQ (98). These measure, for example, excitability and trainability, as well as aggression and fear towards both humans and other dogs. Serpell and Duffy (92) used the C-BARQ to compare the 30 most common breeds in USA and, again, a large 
variation among breeds was found for each behavioural trait. To mention a few, Siberian husky has the lowest stranger-directed aggression and lowest non-social fear, the toy poodle seeks the most attention from its owner, and the Australian shepherd is the breed that is the most trainable.

In Paper I, we were not only interested in comparing the breeds Labrador and golden retriever, we also studied the within-breed differences between the selection lines, common and field type. Our results show that the types differ in all six behavioural traits. To mention but a few, field-type retrievers are less sociable and show less aggression than common-type retrievers. Importantly, for some traits the within-breed differences are even greater than the between-breed difference. Fieldtype Labradors are, for example, as playful as field-type golden retrievers, whereas common-type Labradors are least playful (Paper I). Also previous studies have pointed out behavioural differences between selection lines of breeds, e.g. Labrador retriever and English springer spaniel (99-101).

The consequences of these results are that even though differences in behaviour are found between breeds, there are substantial within-breed differences that should not be neglected. Additionally, Mehrkam and Wynne (86) caution from claims about systematic breed differences because many breeds, especially the less common ones, are underrepresented in research. A systematic review and meta-analysis would be able to teach us more about breed differences and their consistency. Apparently, there are breed-typical behavioural traits, but the behaviour of the individual is much more than its breed.

It has been discussed whether breed differences in general behaviour stems from historical function or if they are rather linked to recent selection. In Svartberg (2006), none of the behavioural traits studied could be related to breeds' historical function. Contrarily, Turcsán, et al. (102) could trace boldness and trainability to historical function. According to Paper I, the recent selection that has created the diversification within Labrador and golden retriever has not affected the behaviour of two breeds in a similar manner. Even though there has been a recent and similar selection pressure for the two breeds, a field-type Labrador behaves differently from a field-type Golden retriever. As all the four groups in Paper I, common and field of the two breeds, share historical function, neither does this explain the differences. Rather, general behaviours not directly targeted by selection may be more affected by genetic processes such as genetic drift, bottlenecks, founder effects, and popularsire effects, or simply different breeders' preferences, than by either historical function or recent selection. 


\subsubsection{Human-directed social skills}

Group differences can also be found among dogs in their human-directed social competence. It has been suggested that breeds historically bred for working may be more successful in the pointing test than non-working breeds (103). Within working breeds, those with the function of working cooperatively with humans seem more successful than those working independently. During a problem-solving test, the herding/hunting group gazed more at the human than the molosser and primitive group (104), again suggesting a link between human-directed social competence and historical function. In congruence, the performance in pointing understanding in the breeds border collie (herder; high cooperation), Airedale terrier (hunter; medium cooperation), and Anatolian shepherd (livestock guardian; low cooperation), decline in that order (105).

In Paper II, we investigate the differences between the breeds German shepherd dog and Labrador retriever, both of which, historically, are two cooperative working breeds. We found that they differ in their human-directed social behaviours. Labrador retrievers performed better in the pointing test and partook in more human eye contact during the problem solving. In the latter test, the German shepherd dogs were instead more passive. A similar difference in gazing behaviour between these two breeds has previously been shown (106). Even though both are comparatively cooperative working breeds, this might still reflect a difference in historical function. It could be argued that a gundog possesses a higher cooperativeness than a herding and guardian dog.

However, maybe it is more relevant to compare based on today's function instead of the historical one. In Paper II, we compare the two subpopulations within the Labrador retriever, the common type and the field type. The field type is still bred for their original function as gundogs, in comparison to the common type where selection has changed to include morphological characteristics and behaviours appreciated in a pet dog. Based on this, we would expect a higher cooperativeness in the field type. As expected, the field type gazed more at the humans than the common type during the problem-solving test (even though both types engaged equally in the test setup). On the other hand, both types were equally successful in following human referential signals.

Studies on breed comparisons in this area of research are surprisingly scarce and if we want to know the effects on human-social competence of selection for different traits, more research is needed. Because of the differences we found in Paper II, we 
can at least suggest that human-directed social behaviours are affected by both ancestral roots and recent selection, and that selection for cooperative tasks may have an effect.

\subsection{Behaviour and morphology}

Some of the behaviour differences found between breeds may be due to differences in morphology. For example, Horschler, et al. (107) show some evidence that brain size accounts for some of the breed differences in cognition. Additionally, by studying behaviours from the Dog Mentality Assessment, Stone, et al. (108) found correlations between behaviour and height, weight, and skull size. Among other things, the results correlated shorter skulls (brachycephalic) to higher aggression and sociability, taller body size to higher activity, and heavier weight to higher playfulness.

Correlations between morphology and behaviour may be due to a genetic correlation between the traits, but some breeds are also likely to experience constraints due to morphological features. For example, behaviours of extreme brachycephalic and giant breeds may be affected by a lack of stamina, and those of extreme chondrodystrophic may be affected by restrictions in their movements $(92,109)$. Moreover, certain traits can affect the dog's perception of their surroundings. Brachycephalic breeds, with short skull and frontally placed eyes, have a region with a very high ganglion cell density, an area centralis, while dolichocephalic breeds with long skulls have a horizontal streak of ganglion cells (110). Thus, a pug might have a higher visual acuity than a whippet, which is expected to affect their way of viewing their world. Indeed, in a study on visual acuity in dogs, a pug outperformed the dolichocephalic individuals (111). 


\section{Genes and environment affect dog behaviour}

Behaviour is always a product of both genetic and environmental factors. Genes control the formation of sensory organs that receive sensory input from the environment, the nervous system that interprets the information, and the muscular apparatus that performs the behaviours (112). Even behaviours that are strongly determined by genetic factors will need environmental input (a herding dog needs something that triggers its herding behaviour), and behaviours strongly determined by environmental factors will need genetic factors (learning how to sit on command).

\subsection{Behavioural genetics}

For behavioural traits to change through selection, genetic variation is required. Because breeds and selection lines differ in behaviours, and the dog differs from the wolf, it suggests a substantial genetic variation and a genetic basis for the traits. The characteristics of the dog genome together with different behaviour profiles of breeds, make the dog an important subject for studies of behaviour genetics.

There are behaviours that follow Mendelian inheritance. In a genetic cross experiment between basenji, with a high threshold for barking, and cocker spaniel, with a low threshold for that same behaviour, Scott (113) found that the cocker spaniel's low threshold is dominantly inherited and that the trait seems caused by only two genes. However, in general, finding the genetic foundation for behaviours has proven more difficult than for morphological traits and diseases. Behaviours are genetically complex with possible multiple genomic regions who each make a small contribution and are greatly influenced by the environment. Also, behaviours might be hard to phenotype with necessary specificity.

A whole-genome comparison of wolf and dog reveals that those genes and regions that show signs of strong selection are mainly involved in brain function and nervous system development pathways, and thus likely connected to behavioural differences (114). Interestingly, another set of genes that shows selection signals are responsible for starch digestion. This suggests an adaptation to the starch-rich diet of humans rather than the carnivorous diets of wolves (114). vonHoldt, et al. (17) found a SNP close to the gene WBSCR17 that displays signs of strong selection. This gene is responsible for Williams-Beuren syndrome in humans, characterised by, among other things, extreme sociability. 


\subsubsection{Heritability of behaviour}

One method of estimating the amount of genetic contribution to a trait is to calculate the narrow-sense heritability. Narrow-sense heritability $\left(h^{2}\right)$ is an estimate of the proportion of the total phenotypic variation that is caused by additive genetic factors in a population, or, more simply, an estimate of how much of the phenotypic variation can be explained by variation in genes rather than environment. By knowing the relatedness of individuals in a population and having individual data on behavioural traits we can estimate the genetic contribution to behaviour variation. Heritability estimates can be used in selection to predict phenotypic change from one generation to the next:

$$
\text { parental deviation from population } \times h^{2}=\text { change in offspring }
$$

Heritability estimates have been used to find a significant genetic contribution to several behavioural traits in dogs. For example, human-directed social interactions measured during problem solving in a population of beagles had a heritability of 0.22 (77). Thus, $22 \%$ of the variation in the behaviour depended on genetic variation. Also, heritability estimates for behavioural traits from the Dog Mentality Assessment have been reported for the breeds rough collie, Rottweiler, German shepherd dog, Labrador retriever and golden retriever (Paper I; 115, 116, 117), and are overall moderate in size (0.1-0.4). For instance, in Paper II, the heritability for playfulness was 0.35 and 0.13 , in golden and Labrador retrievers, respectively, and for curiosity it was 0.30 and 0.32 .

In Paper I we identified differences in heritability between the selection lines of the Labrador retriever and golden retriever. This is an indication of differences in selection pressure for the types. Indeed, genetic variation is affected by selection (118). It is important to realise that the heritability estimates may vary between populations, and generations, and differences in heritability estimates between studies are rather expected (119).

\subsubsection{Finding the genes}

When a trait has a known genetic contribution, it is possible to identify involved genes by associating phenotype with genotype. One way of finding genetic regions of interest is to use genome-wide association studies (GWAS). The heritable and variable traits are tested if they are associated with any genetic markers in the genome, a method the dog genome is well suited for (see section 2.3). 
This approach was used in Persson, et al. (120) where two genetic regions on chromosome 26 were associated with human-directed social behaviour in laboratory beagles. The SNPs are located within SEZ6L and ARVCF, and in the same linkage disequilibrium block are also COMT, TXNRD2, and TANGO2. In Paper III, we verify that these SNPs are associated with social behaviour in dogs by testing the additional breeds Labrador and golden retriever. Through inclusion of both common- and fieldtype Labradors, we also know that recent selection has affected allele frequencies for both polymorphisms as it varies between the types (Paper III). Previous associations with these genes include autism (SEZ6L), schizophrenia (ARVCF), and mood regulation (COMT) in humans (121-123). Most interestingly, COMT SNPs have been linked to fear reactions measured in the Dog Mentality Assessment (124), and to dogs' activity levels (125). In Paper III, we tentatively suggest that these regions may have been important during domestication.

As previously stated, vonHoldt, et al. (17) identified a genetic region in the dog genome that showed strong signals of selection and that in humans is responsible for Williams-Beuren syndrome. This region was further investigated in vonHoldt, et al. (126), and structural variants of the genes GTF2I and GTF2IRD1 (transcription factors) could be strongly linked to human-directed social behaviours in dogs. These genes have previously been linked to hypersocial behaviours in humans with Williams-Beuren syndrome and in mice $(127,128)$. The variants are transposable elements, an element that has been suggested to have had impact on domestication. Transposons at a low copy number could be present in the ancestral genome and become functional due to rapid amplification as a response to intense selection (129).

There are also other candidate genes that have been indicated for being involved in dogs' social behaviour, for example hormones and neurotransmitters.

Polymorphisms in the oxytocin receptor gene $(130,131)$ and the opioid receptor gene (132) are associated with human-directed social behaviours, and polymorphisms in dopamine and serotonin related genes are associated with human-directed aggression (133).

GWA studies have identified loci of interest for general behaviours as well. Ilska, et al. (134) found several associations between SNPs and behavioural traits in Labrador retrievers, many in or close to genes known to regulate neurological or behavioural functions. For example, a genetic marker associated with agitation is close to the TH (tyrosinase hydroxylase) gene, involved in synthesis of a dopamine precursor, and the SNP associated with barking is located close to CLINT1 (Epsin 4), a gene previously associated with schizophrenia. A recent study on noise sensitivity and 
fear of strangers in German shepherd dogs found two genetic regions that reached genome-wide significance. Interestingly, these regions include known neuropsychological and hearing-related candidate genes (135).

Importantly, SNPs associated with phenotype are likely not causative. Further studies are required to find the structural variants that are, as was done in vonHoldt, et al. (126). However, by locating loci of interest, this will considerably narrow the search for functional elements.

The effects of certain genes may vary across dogs. In Paper III, the associations between behaviour and the SNPs differ between Labrador and golden retriever. For example, one of the genetic markers affects physical contact in golden retriever and gazing behaviour in field Labrador retrievers, but not in the common type. Another example shows that genetic effects may be sex specific. Konno, et al. (136) linked a specific allele on the androgen receptor gene to aggressive behaviour in akita inu, but only in male dogs as it did not affect female aggression. Thus, even though when genes are found to contribute to a behaviour, they may not affect all dogs. That is why it is important to verify results in other groups, as was done in Paper III.

\subsection{Environmental effects}

An individual's experiences and surroundings will be part of forming its behaviour. Actually, experiences of the parents may already have an effect. In chickens, Ericsson, et al. (137) show how stress exposure early in a female's life not only affects its own behaviour as an adult, but also the behaviour of its subsequent offspring.

\subsubsection{Early experiences}

Effects of early experiences have been shown to have a great effect on later adult behaviour in many species. This is also true in dogs, and for example the mothers' level of care for her puppies has an effect. A higher level of maternal care in military German shepherd dogs positively affected the puppies performance in a suitability test at 18 months (138). Interestingly, the opposite was found in guide dogs where more maternal care was linked to failure of the training program (139). Additionally, early-life variables such as season of birth, the size of the litter it is born in, and the ratio of females and males in the litter impacts adult dog behaviour (140).

Human interactions will affect the puppy as well. As previously mentioned, if dogs have no interactions with humans during the so-called critical period (about 2-14 
weeks) they will show strong human-directed fear and struggle to form attachment to humans (82). The level of human handling during the puppies' first weeks will also affect them (141). An extensively handled group outperformed normally handled control puppies in solving a puzzle and showed less anxiety and more human interest when five weeks old. A third group was socially isolated between four and five weeks of age (single housing, darkened room, very limited human contact), and these puppies were hyperactive, had low problem-solving skills, high anxiety, and showed very little human interest. A more recent study found that daily, gentle handling until 3 weeks of age resulted in lower emotional (stress) reactivity in an open-field test at 8 weeks (142).

A comparison between dogs bought as puppies from non-commercial (hobby/home) breeders versus those from pet stores, and thus coming from commercial (puppy farm) breeders, points out the impact early experiences can have. The latter group, raised in a stressful environment with limited human contact, had increased aggression, fear, and separation anxiety compared to puppies from non-commercial breeders (143).

\subsubsection{Environmental effects on human-directed social behaviours}

There is some evidence that dogs' performance in tests of their human-directed social skills are affected by environment and experiences of the dog. For example, in a comparison of pointing understanding between pet and kennel golden retrievers, the latter group, with comparably limited human contact, understood proximal but not distal gestures, whereas pet dogs were successful in both conditions (144). In a similar cohort of Labrador retrievers tested in the problem-solving paradigm, kennel dogs showed less gazing than pet dogs while spending equal amount of time interacting with the test setup (145). On the contrary, Gácsi, et al. (59) found no effect of housing condition or owner-interaction time on the performance in the pointing test.

Whereas the training amount in general does not seem to influence dogs' understanding of referential gestures (Paper II), gundog training (retrieving) is linked to a higher performance (Paper II; 58). Gundog training involves directional gestures and this is to be expected. Agility training, on the other hand, did not influence pointing success (59), but it seems to affect problem-solving behaviours. In a comparison between pet, agility, and search-and-rescue dogs, Marshall-Pescini, et al. (146) found different strategies between the groups. Agility dogs gazed at the 
human more, search-and-rescue dogs barked more, and pet dogs exhibited the least gaze alternations.

\subsubsection{Owners' effect on dog behaviour}

Dogs live in an anthropogenic environment and many times, primarily in the Western world, together with a human owner. Their lives are, to a great extent, decided by their human caretakers. The everyday life of the owner is shared by the dog, and the dogs' daily activity is mainly dependent on the owner. An example of how owner's affect dogs is that aversive training methods have been associated with behaviour problems in dogs (147). There are also more intricate effects based on the human-dog social bond. The owner's attachment and interaction style, as well as aspects of the owner's personality, have been shown to influence the relationship and the dog's behaviour (148-150).

Group-living animals often exhibits behavioural synchronization by doing the same thing, at the same time and place, and this seems to also strengthen bonds within the group (151). Primarily, synchronization is intraspecific, but an interspecific behavioural synchronization has been found within the dog-human dyad. Dogs stay in proximity of their owners, change activity when the owners do, and move at the same pace $(152,153)$. Additionally, dogs may prefer humans that synchronize their activity to that of the dog, which suggests that behavioural synchrony affects the dog-human relationship (154).

Social referencing also occurs between owners and dogs. Similar to human and chimpanzee infants, dogs take emotional cues from their human caregiver for how to behave in a novel situation (155). When faced with a novel, potentially threatening, stimulus, puppies alternated their gaze between object and caregiver and approached the stimulus more readily if the caregiver showed positive emotions towards it (156).

\subsubsection{Stress and dog-human interactions}

A stressor, i.e. a potential external or internal threat, will activate a cascade of reactions, for example the neuroendocrinal HPA axis which will result in increased levels of glucocorticoids, cortisol in dogs. Cortisol concentrations in saliva, blood plasma, and hair can therefore be used as a biomarker for stress. Cortisol concentrations, however, also show diurnal rhythm, seasonal effects, and are affected by activity, and should therefore always be interpreted with care. Whereas blood 
plasma and saliva only measure the instantaneous stress reaction, hair can be used to study long-term cortisol concentrations as cortisol is incorporated into the hair as the shaft grows (157). By measuring hair cortisol in dogs, dogs' long-term stress levels could be linked to lifestyle (pet, competing, or police dog) in German shepherd dogs (158).

Positive interactions between dogs and humans are associated with wellbeing in both species. In shelter dogs, interactions with humans increase dogs' welfare by decreasing behavioural signs of distress and decreasing plasma cortisol concentrations (159). Interestingly, among a group of German shepherd dogs, owners that played more with their dogs had dogs with lower hair-cortisol concentrations (158). This suggest that positive human interaction has the potential of decreasing stress in dogs. Dogs, in turn, have a positive effect on humans, for example as a social supporter (160), and it has been shown that having a dog in the classroom decreases students' aggressive and hyperactive behaviour and increases their attention towards their teacher (161).

In Paper IV, we investigated the emotional contagion between dogs and their owners. Emotional contagion is the mirroring of emotional state between individuals and has frequently been observed within group-living species (162). Stress, for instance, can be highly contagious among individuals of the same species (163), and even interspecifically between dogs and their owners (Paper IV; 164). It has been shown that an owner's perceived stress during testing can have a significant impact on their dog's memory performance (165). Also, there is evidence of synchronization of cortisol concentrations between dogs and their owners. Buttner, et al. (164) identified this on short-term stress between agility dogs and their handlers. After an agility run, the dyad showed a correlated increase of saliva cortisol. In Paper IV, we studied the long-term cortisol by using hair samples from both dogs and their owners. We found that dogs and their owners are synchronized in long-term cortisol (Fig. 4). To my knowledge, this has previously only been seen between human mothers and their children $(166,167)$. The synchronization was found in both pet and competing dogs, but was stronger among the competing dyads. Importantly, there was no effect of activity on cortisol concentrations. This implies that the mirroring of long-term stress is affected by emotional contagion between the two species and not simply due to lifestyle effects (Paper IV).

Paper IV also shows an effect of owner personality on dogs' stress levels, whereas the dog's own personality traits had little effect. Owners scoring high on conscientiousness and openness had dogs with higher cortisol concentrations, and 
owners scoring high on neuroticism had dogs with lower concentrations. Interestingly, this is consistent with previous results on how owners' and dogs' personality traits influence short-term stress levels in dogs (168-171). Thus, it seems that the owner has the greater influence on dog cortisol concentrations within the dyad and that dogs reflect the stress of their owners.

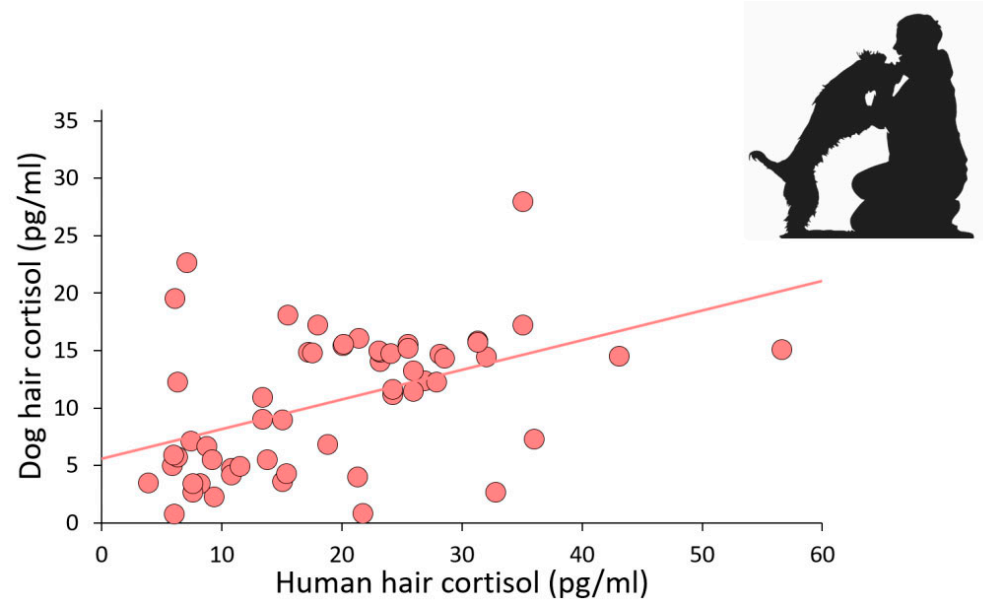

Figure 4. Synchronisation in hair cortisol concentrations between dogs (Shetland sheepdog and border collies) and their female owners (58 dog-human dyads).

\subsubsection{Are we measuring effects of life-history or differences between genetic isolates?}

That a dog's life experience and its owner affect dog behaviour is important to take into account when comparing groups of dogs. There may even be consistent differences in the environments for different breeds, for example in training amount, lifestyle, or owner characteristics. Certainly, breeds' behaviours are inherently different, but this may also attract people with different intentions and lifestyles that potentially will further increase the differences. Indeed, among the Labrador retrievers used in Paper II and III, owners of the common type declared more often that they got their dog as a companion dog than owners of the field type, who instead stated more often that they got their dogs for training purposes. When Marshall-Pescini, et al. (172) compared trained (competition level) to untrained dogs from four different breed groups in cognitive tasks, training seemed to have had a larger effect than breed, but few studies have systematically investigated this.

Potential environmental differences between breeds are quite apparent when comparing extremes. It is intuitive that the life of a Great Pyrenees will likely differ 
considerably from the life of a Belgian Malinois, and the English bulldog's life from that of the Karelian bear dog. They may attract people of different lifestyles, interests, and stress-resiliencies. Maybe even of different personalities; for sure, differences in personality have been identified between 'dog people' and 'cat people' (173). This is something for future studies to further explore.

\subsection{Epigenetics - the mediator between environment and genes}

Epigenetics is the study of those processes that affect the expression of genes without changing the DNA sequence and that are mitotically and/or meiotically heritable (174). Whereas the DNA sequence is static, epigenetic factors are dynamic and can act as the mediator between environment and genes, and contribute to phenotypic plasticity. In response to changes or challenges in the environment there may be epigenetic modifications that could facilitate an adaptive response by geneexpression change (112).

Epigenetics factors include DNA methylation, histone modifications, and non-coding RNAs. DNA methylation, a methyl group at CpG dinucleotides, is the most commonly studied epigenetic factor (Fig. 5). CpG islands, i.e. repetition of CpGs in the DNA sequence, are frequently found in promotor regions of genes, and the methylation may thus alter gene expression, specifically by down-regulating or gene silencing $(175,176)$.

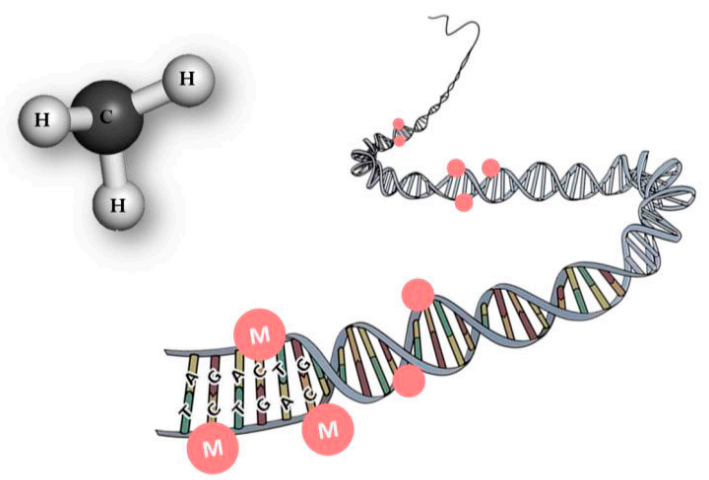

Figure 5. DNA methylation. A methyl group (molecule to the left) binds to cytosine, one of the nitrogenous bases found in DNA. 


\subsubsection{Epigenetics and behaviour}

We do know that early experiences affect dog behaviour (see section 4.2.1). Whereas the mechanisms for this is not yet known in dogs, there are more studies performed in other species. The level of maternal care, for example, has long-term effects not only in dogs but also in mice. In mice, low maternal care is associated with higher glucocorticoid levels in adult offspring (177). By comparing offspring of high and low caring mothers, a difference in the epigenome in the promoter region of a glucocorticoid receptor was found (178). Specifically, offspring receiving low maternal care have a hypermethylation of the region, and, consequently, a downregulation of gene expression. Individual experiences may also have transgenerational effects, which has been shown in a variety of species. In chickens, early-life stress in females will alter brain gene expressions not only in her, but also in her offspring (137), and in humans, methylation patterns of the grandchildren to women exposed to violence during pregnancy differ from controls (179).

This is a new area of research, and studies on dog behaviour and epigenetic factors are scarce. As the first of its kind, Cimarelli, et al. (180) could associate dog's social behaviour to DNA methylation of the oxytocin receptor gene. In males, a lower methylation level was associated with approaching a threatening stranger and a higher level with hiding behind their owner. Females with higher methylation levels approached the stranger more readily, and in a friendly manner, compared to those with lower levels (180).

Interestingly, Cimarelli, et al. (180) also tested if owner interaction style affects methylation of dog's oxytocin receptor gene. They did not find an association between the two. However, based on the results in Paper IV where we find a synchronization of cortisol levels between owners and dogs, this area of research is highly intriguing. I expect future explorations of similar associations, perhaps between owner personality and methylation of glucocorticoid receptors, to identify important epigenetic mechanisms on how owners affect their dogs.

\subsubsection{Epigenetic modifications and domestication}

It has been suggested that epigenetics is an important factor in evolutionary processes, for example in domestication and speciation (181-183). Epigenetic factors affect gene expression and phenotype (and social behavior: 180, e.g. coat color: 184), they have been shown to be heritable $(185,186)$, and they promote genetic mutations (187). 
Few structural differences are found in genome-sequence comparisons of dogs and other canines. However, gene-expression patterns in dogs are markedly different from the conserved patterns of wolves and coyotes (188). Similar findings have been reported between domesticates and ancestors of other species (189). This implies that epigenetics may play an important role in changing the gene expression in domesticated species. Consequently, Nätt, et al. (190) compared DNA methylation patterns in promotor regions in brain samples from domesticated chickens and their ancestor, and found differences that could be associated with gene-expression differences.

In Paper V, we compared differentially methylated regions between wolf and dog as well as within dogs, i.e. across breeds, using DNA samples from the frontal cortex of the brain. Previous studies have identified methylation differences in blood and buccal samples between wolf and dog $(129,191)$. Because DNA methylation is highly tissue specific (192), the brain is the main organ of interest from a behavioural perspective.

Paper V showed substantial DNA methylation differences between wolf and dog (Fig. 6) as well as between the dog breeds. In the comparison between wolf and dog, the significant differentially methylated regions were more methylated in wolves than in dogs. The methylation profiles of wolf compared to dog and wolf compared to breeds imply that epigenetic factors have been important in the domestication process from wolf to dogs. Eight different breeds were also compared; beagle, boxer, German shepherd, Great Dane, Labrador retriever, pitbull terrier, Rottweiler, and walker hound. The divergence between the breeds could clearly be seen in the substantial differences of differentially methylated regions. The boxer showed the largest difference in DNA methylation and German shepherd dog had the lowest difference compared to the other breeds. The boxer also showed high levels of hypermethylation, whereas the opposite was found in beagle, Great Dane and pitbull terrier. Because of the large differences between breeds, it seems that DNA methylation has been, and still is, important for domestication as well as breed formation (Paper V).

The DNA methylation differences also occur in genes of high interest for the variation found in morphology and behaviour of dogs. Similar to Janowitz Koch, et al. (129), in Paper V we identified that genes that are involved in neurobiological processes are differentially methylated between the wolves and dogs, for example genes related to neurotransmitters. A change in gene expression of these genes may surely affect behaviour and development. For morphology, differentially methylated 
genes include hox genes, which are involved in forming appendicular skeleton (193). Pugs have typical vertebral anomalies consistent with altered hox (194). Also, genes involved in the IGF1 signalling pathway were found to be differentially methylated. IGF1 determines the size of dogs (195), and is associated with anxious behaviour (196).

DNA methylation of the genes identified in Paper V may affect gene expression, and consequently, phenotype. Therefore, it is very probable that at least some of the DNA methylation differences that has been identified are a part of the impressive phenotypic variation among dogs.
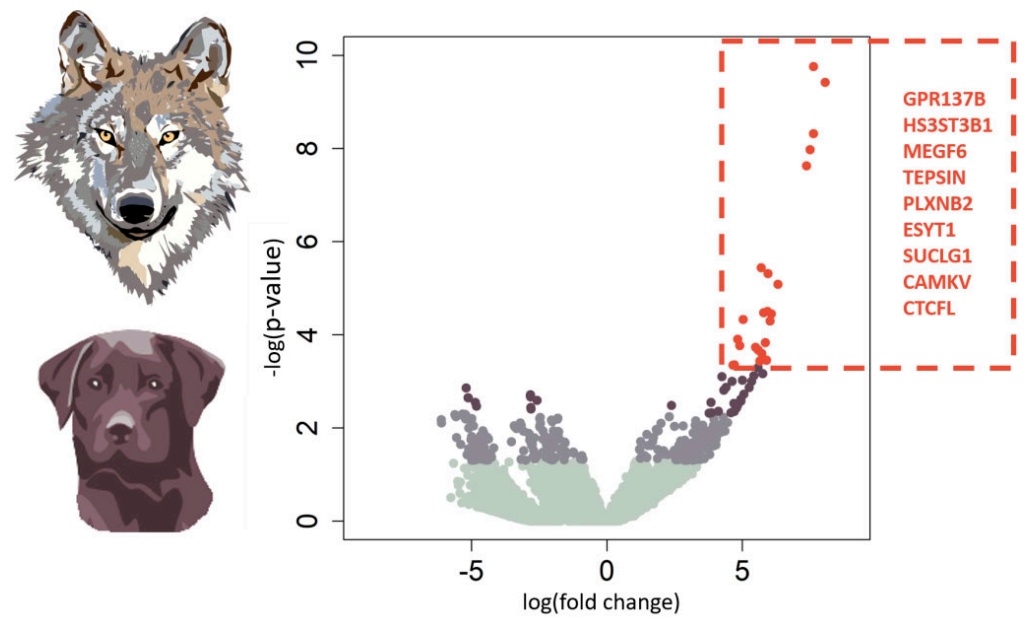

Figure 6. Volcano plot over the methylated regions that are different between wolf and dog. Colours represent significant levels (from bottom to top: $p>0.05,<0.05$, $<0.005,<0.0005)$. Differentially methylated regions with a positive log fold change are more methylated in the wolf than the dog. The regions that reach the highest level of significance are listed to the right of the graph. 


\section{To conclude}

This thesis highlights the intricate picture of dogs' behaviour. It is rooted in the behaviour of wolves but formed during domestication. Breed formation has led to consistent behavioural differences between populations, but a dog is more than its breed. Subpopulations within a breed are affected by different selection pressures that will influence their behaviour. The selection pressure will not affect different populations similarly, though, and differences in general behavioural traits seem influenced by differences in genetic architecture rather than recent or historical selection (Paper I). Dogs' human-directed hypersociability may be affected by selection, also recent selection, for higher human cooperativeness. Dogs' sociability is multifaceted, however, and a dog good at one social-cognitive task is not necessarily good at the next (Paper II). There is also an individual variation in behaviour among populations, and there is a clear association with this variation and genetic variants (Paper III). A dog's behaviour is not only explained by genetics, however. The dog's experiences and, maybe especially, its owner will influence the dog greatly (Paper IV). Epigenetic factors are influenced by the environment and affects gene expression; therefore, it can also affect behaviour. By epigenetic influence, a dog's behaviour could even be affected by the environment of its great-grandparents. Epigenetic effects surely have their part in variation among dogs (Paper V).

Why your dog behaves in a certain way? It is complex. 


\title{
Summary of papers
}

\section{Paper I}

\author{
Similar recent selection criteria associated with different behavioural effects in \\ two dog breeds \\ Ann-Sofie Sundman, Martin Johnsson, Dominic Wright, Per Jensen, 2016. Genes, \\ Brain and Behavior, 15(8), pp.750-756. \\ http://doi.org/10.1111/gbb.12317
}

\begin{abstract}
Background and aim
During domestication, human selection of dogs resulted in different dog types and later in different breeds with closed genetic pools. However, selection has continued, and, in some breeds, the different aims of the breeders have resulted in different types within the breeds. One example of this is within the golden and Labrador retriever where there are two established types, the common type bred for conformation and as a pet, and the field type bred for hunting abilities. The aim of the present study was to explore behaviour differences between the two retrievers and between the two breed types. By calculating heritability estimates, we could also compare the genetic contribution.
\end{abstract}

Method

We studied behaviour data from a standardized behavioural test, the Swedish Dog Mentality Assessment (DMA). Results from 902 goldens (689 common and 204 field) and 1672 Labradors (1023 and 649) were used, tested between 2005 and 2014. By studying pedigrees, the dogs were classified as either common or field type.

\section{Results and discussion}

Principal component analysis revealed six behavioural components from the DMA data: curiosity, play interest, chase proneness, social curiosity, social greeting and threat display. The effects of breed, type, age and sex on the components were tested by general linear models. Breed and type affected all behaviours. For example, Labradors were more curious than goldens $\left(\mathrm{F}_{1,2568}=360.874, \mathrm{p}<0.001\right)$ and the field type was more playful than the common type $\left(\mathrm{F}_{1,2565}=86.004<0.001\right)$. However, there was also an interaction between breed and type for all behaviours but threat display, implying that the differences between the types are not the same across breeds. For example, in the Labrador retriever, the common type showed higher curiosity than the field type $\left(\mathrm{F}_{1,1668}=18.359 ; \mathrm{p}<0.001\right)$, while the golden retriever field typed dogs displayed higher curiosity than the common type $\left(\mathrm{F}_{1,897}=65.201 ; \mathrm{p}<0.001\right)$. In both breeds, heritability estimates for the behaviours were moderate, indicating that there was a considerable genetic contribution to the variation in behaviours. There was also variation in heritability between the breeds and the breed types, suggesting a difference in genetic variance due to different selection pressures. In conclusion, even though the golden and Labrador retrievers have both a similar origin, are closely related, and have a similar split between a common and a field type, we show that the types behave differently across the breeds. We therefore suggest that the genetic architecture related to behaviour differs between the breeds. 


\section{Paper II}

\section{Understanding of human referential gestures is not correlated to human-directed social behaviour in Labrador retrievers and German shepherd dogs}

Ann-Sofie Sundman, Mia E. Persson, Anna Grozelier, Lise-Lotte Halldén, Per Jensen, Lina S.V. Roth, 2018. Applied Animal Behaviour Science, 201, pp.46-53.

http://doi.org/10.1016/j.applanim.2017.12.017

\section{Background and aim}

During domestication, dogs have developed specific skills when it comes to human communication and they excel at both communicating with humans and following human communicative cues. Two experiments commonly used to study these skills are the problem-solving test, where the dog is tested on how much contact they seek with the human, and the pointing test, where the dog is tested on how well they follow human gestures. The aim of this study was to compare behaviours in the two tests to see if dogs that seek more human contact also understand humans' communicative cues better. Additionally, we were interested in investigating breed differences and breed type differences.

\section{Method}

153 dogs of the breeds German shepherd dog (GSD; 16 females and 16 males) and Labrador retriever (63 females and 58 males) were included in the study. Labradors were divided into breed types common ( 35 females and 25 males) and field type (28 females and 33 males) based on ancestry. The problem-solving apparatus was a plate with three identical compartments containing treats, two with lids that could be opened and one that could not be opened by the dogs. The dogs' test-oriented and human-oriented behaviours were scored. In the pointing test, we used a momentary distal pointing cue and measured their success rate in 20 trials.

\section{Results and discussion}

The behaviours scored during the problem-solving test were reduced using a principal component analysis which revealed four components: Passivity, Experimenter Contact, Owner Contact and Eye Contact. Differences between the GSD and the Labrador were found for all four components. The GSD scored higher for Passivity and Experimenter and Owner Contact while Labradors sought more Eye Contact. The Labrador breed types differed for Owner Contact and Eye Contact where the field type scored higher. In the pointing test, all groups of dogs performed better than chance, but the Labradors performed better than the GSD. There was no difference between the breed types in pointing performance. In the comparison of the two tests, neither Passivity, Experimental Contact or Eye Contact had an effect on pointing performance. For Owner Contact, there was a negative correlation to pointing performance, but this was only present in the common-typed Labradors. Because we found no positive correlations between the two tests, we conclude that human-directed behaviour during a problem-solving situation does not affect the ability to follow human pointing cues and suggest that these two tests measure different aspects of dogs' social behaviour. The breed and type differences found show that human-directed social behaviour have been affected by both early selection (breed) and recent selection (breed types). 


\section{Paper III}

Sociality genes are associated with human-directed social behaviour in golden and Labrador retriever dogs

Mia E. Persson, Ann-Sofie Sundman, Lise-Lotte Halldén, Agaia J. Trottier, Per Jensen, 2018. PeerJ, 6, p.e5889. http://doi.org/10.7717/peerj.5889

\section{Background and aim}

There is a genetic contribution to individual variation in dogs' human-directed social behaviour during a problem-solving test and previous research has found two single nucleotide polymorphisms associated with social behaviours during a problem solving in beagles. The aim of this study was to investigate if these genetic regions are also associated with social behaviours in other breeds. We also compared allele frequencies between groups by sequencing this region in both dogs and wolves and two different breed types.

\section{Methods}

A total of 161 dogs were tested in a problem-solving test and genotyped. The dogs were of the two breeds Golden retriever ( 34 females and 27 males) and Labrador retriever ( 52 females and 48 males). The Labradors were further divided into the breed types common type ( 28 females and 24 males) and field type ( 24 females and 24 males). We also genotyped 21 wolves ( 7 females and 14 males). The problem-solving test consisted of a plate with three compartments containing treats, two of which with lids that could be opened by the dogs and one that could not be opened. The dogs' humandirected social behaviours were scored. DNA from dogs (buccal swabs) and wolves (blood or brain tissue) was genotyped on two of the previously identified SNPs, BICF2G630798942 (SNP1) and BICF2S23712114 (SNP2), by pyrosequencing.

\section{Results and discussion}

Associations between the two SNPs and social behaviours during the problem-solving test were found in both dog breeds and for different behaviours. In goldens, SNP1 was associated with physical contact variables. SNP2 was associated with several of the measured behaviours, for example gazing frequency in both breeds (goldens: $F_{2,55}=6.330, p=0.003$; Labradors: $F_{1,93}=5.209, p=0.025$ ). Moreover, there was a genetic variation for both SNPs in both dog breeds whereas wolves were fixed for SNP1. Common and field type Labradors differed in allele frequencies for both SNP1 and SNP2, which suggests that these SNPs have been affected by recent selection. These results show that these genetic regions are not only associated with human-directed social behaviour in beagles, but in other dog breeds also. We tentatively suggest that these regions have been important during domestication. 


\section{Paper IV}

\section{Long-term stress levels are synchronized in dogs and their owners}

Ann-Sofie Sundman, Enya Van Poucke, Ann-Charlotte Svensson-Holm, Åshild

Faresjö, Elvar Theodorsson, Per Jensen, Lina S.V. Roth, 2019. Submitted manuscript.

\section{Background and aim}

Emotional contagion occurs not only within species but may also occur between species, for example between dogs and humans. Previous research shows a synchronization in short-term stress within the dog-human dyad, and since owners often share everyday life and environment with their dogs this may lead to an interspecific long-term stress hormone synchronization. Our aim in this study was to investigate interspecific contagiousness of long-term stress by using dogs and their owners.

Methods

58 dog-human dyads were included in the study and hair from both dogs and their owners were analysed for their concentration of hair cortisol, which gives a measure of long-term stress. The hair cortisol was extracted using radioimmunoassay. Hair was taken on two different occasions, reflecting cortisol levels during summer and winter months. The dogs were of two different breeds, Shetland sheepdog (18 females and 15 males) and border collies (13 females and 12 males). The dogs were grouped into either companion (15 Shetland sheepdog and 11 border collies) or competing dogs (18 Shetland sheepdogs and 14 border collies). Owners' and dogs' personalities were assessed through owner-completed Dog Personality Questionnaire and Big Five Inventory. To investigate the activity levels of the dogs they wore a PetPace ${ }^{\mathrm{TM}}$ smart collar for seven days that continuously recorded activity data.

\section{Results and discussion}

The results show a clear synchronization in hair cortisol concentrations between dogs and their owners on two separate occasions (summer: $\mathrm{N}=57, \chi 2=23.697, \mathrm{P}<0.001, \beta=0.235$; winter: $\mathrm{N}=55$, $\chi 2=13.796, P<0.001, \beta=0.027$ ). The synchrony was affected by sex and lifestyle. Female dogs and their owners showed a stronger synchronization than male dogs and their owners, and the synchrony was stronger in competing dyads than pet dyads. Furthermore, the cortisol concentration was not affected by dogs' activity levels nor their personality. However, the personality of the owners had an effect on the dogs' long-term stress. Higher scores for Neuroticism in the owner had a negative association and scores on Conscientiousness and Openness had a positive association with dogs' hair cortisol concentrations. Since the personality of the owners, but not the personality of the dogs, was related to long-term cortisol concentrations in the dogs, the results imply that dogs mirror the stress levels of their owners. 


\title{
Paper V
}

\section{DNA methylation in canine brains is related to domestication and dog-breed formation}

\author{
Ann-Sofie Sundman, Fàbio Pértille, Carlos Guerrero-Bosagna, Luiz Lehmann \\ Coutinho, Elena Jazin, Per Jensen. Manuscript.
}

\begin{abstract}
Background and aim
Epigenetic factors, e.g. DNA methylation, acts as mediators in the interaction between genome and environment. Variation in the epigenome can both affect phenotype and be inherited, and has therefore been suggested to be an important factor in the evolutionary process, e.g. in domestication. Dogs are not only our oldest domesticated species, they also show an extreme diverse in morphology and behavior. Thus, canines are a good model for studies of epigenetic involvement in diversification. The aim of this study was to explore DNA methylation in wolf, dog, and different dog species.
\end{abstract}

\footnotetext{
Methods

In this study, genomic DNA from the frontal cortex of 38 dogs of eight breeds and of three wolves were extracted. We optimized a combined method of genotype-by-sequencing (GBS) and methylated DNA immunoprecipitation (MeDIP) for application in canines. From this, we get a reduced representation of the canine genome. Two libraries (GBS and GBS-MeDIP) were prepared and sequenced on Illuma HiSeq2500 platform and were analyzed by bioinformatic tools.

\section{Results and discussion}

By performing a neighbor-joining tree analysis, we conclude that our reduced sample is representative of the dog genome as wolf and dog breeds cluster according to group. In the methylation analysis, substantial DNA methylation differences between wolf and dog and between the dog breeds are found. The methylation profiles of the different groups suggest that epigenetic factors have been important in the speciation from dog to wolf and also in the divergence into dog breeds. We highlight methylation differences in genes related to behavior and morphology, that may alter gene expression and phenotype. We hypothesize that these differences are involved in the phenotypic variation found among dogs.
} 


\section{Acknowledgments}

A list of thank you's:

To my main supervisors Lina Roth and Per Jensen. Lina, thank you for all your support and for the great time we have been having brainstorming ideas, and when talking about everything and anything. Pelle, thank you for giving me this opportunity and for always answering questions and keeping your door open. To my supervisor Carlos Guerrero-Bosagna, and collaborator Fàbio Pértille, for making the epigenetics possible.

To dear colleagues at the biology department, old as well as new, for contributing to a work environment that I have enjoyed being part of. To technicians Tove, AnnCharlotte, Lejla, and Petros, for making everything run smoothly and for helping out in times of need. To master students involved in my projects (or if it was I who was involved in yours?). To Enya, both for your fantastic master's work and for proofreading this thesis wearing your strict English glasses. To my fellow PhD students for support and ear-lending and fun and laughter and all the help. I miss those who left before me and I will miss the ones I will leave behind.

To Tove and Louise, thank you for 9:30s. And all other times. You are important to me. To Lejla, who has been missed. To my office, the very best. To LiU-eliten for giving me energy. It is always a boost to meet you, let us keep it up for ever and ever. To family and friends, those not already included, for always welcoming me and supporting my choices. To the bestest of nephews, Algot, for putting a smile on my face whenever you are around. To Leona, for your amazing photos.

To my dogs, for reminding me what is real. 


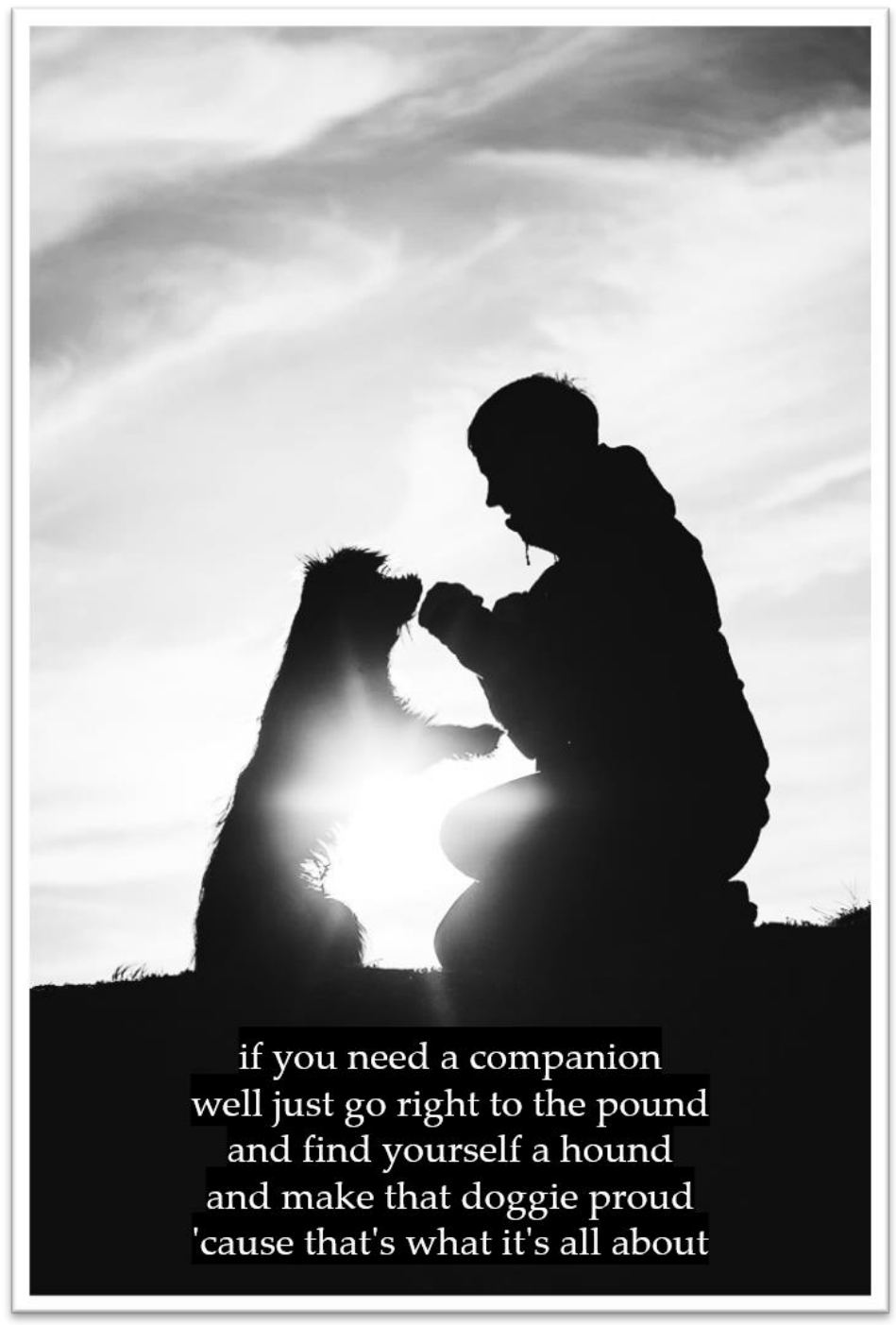

The Dog Song by Nellie McKay Photo: Leona Örtenberg 


\section{References}

1. Scott JP \& Fuller JL (1965) Genetics and the Social Behavior of the Dog (University of Chicago Press, Chicago).

2. Jones AC \& Gosling SD (2005) Temperament and personality in dogs (Canis familiaris): A review and evaluation of past research. Applied Animal Behaviour Science 95(1-2):1-53.

3. Kaminski J \& Nitzschner M (2013) Do dogs get the point? A review of dog-human communication ability. Learning and Motivation 44(4):294-302.

4. Hall NJ \& Wynne CDL (2012) The canid genome: behavioral geneticists' best friend? Genes, Brain, and Behavior 11(8):889-902.

5. Darwin CR (1868) Variation of plants and animals under domestication.

6. Olsen SJ \& Olsen JW (1977) The Chinese wolf, ancestor of New World dogs. Science 197(4303):533-535.

7. Wayne RK (1993) Molecular evolution of the dog family. Trends in Genetics 9.

8. Vilà C, et al. (1997) Multiple and ancient origins of the domestic dog. Science 276.

9. Larson G, et al. (2012) Rethinking dog domestication by integrating genetics, archeology, and biogeography. Proceedings of the National Academy of Sciences 109(23):88788883.

10. Pang JF, et al. (2009) mtDNA Data Indicate a Single Origin for Dogs South of Yangtze River, Less Than 16,300 Years Ago, from Numerous Wolves. Molecular Biology and Evolution 26(12):2849-2864.

11. Savolainen P, Zhang YP, Luo J, Lundeberg J, \& Leitner T (2002) Genetic evidence for an East Asian origin of domestic dogs. Science 298(5598):1610-1613.

12. Freedman AH, et al. (2014) Genome Sequencing Highlights the Dynamic Early History of Dogs. PLoS Genetics 10(1).

13. Leathlobhair MN, et al. (2018) The evolutionary history of dogs in the Americas. Science 361(6397):81-85.

14. Skoglund P, Ersmark E, Palkopoulou E, \& Dalén L (2015) Ancient Wolf Genome Reveals an Early Divergence of Domestic Dog Ancestors and Admixture into High-Latitude Breeds. Current Biology.
15. Botigué LR, et al. (2017) Ancient European dog genomes reveal continuity since the Early Neolithic. Nature communications 8:16082.

16. Ding ZL, et al. (2012) Origins of domestic dog in Southern East Asia is supported by analysis of Y-chromosome DNA. Heredity 108(5):507514.

17. vonHoldt BM, et al. (2010) Genome-wide SNP and haplotype analyses reveal a rich history underlying dog domestication. Nature 464 .

18. Thalmann O, et al. (2013) Complete Mitochondrial Genomes of Ancient Canids Suggest a European Origin of Domestic Dogs. Science 342(6160):871-874.

19. Frantz LA, et al. (2016) Genomic and archaeological evidence suggest a dual origin of domestic dogs. Science 352(6290):1228-1231.

20. Zeder MA (2012) Pathways to animal domestication. Biodiversity in agriculture: domestication, evolution, and sustainability:227259.

21. Morey DF (1994) The early evolution of the domestic dog. American Scientist 82(4):336-347.

22. Hare B, Wobber V, \& Wrangham R (2012) The self-domestication hypothesis: evolution of bonobo psychology is due to selection against aggression. Animal Behaviour 83(3):573-585.

23. Horowitz A (2014) Domestic dog cognition and behavior. The Scientific Study of Canis familiaris, (Springer).

24. Belyaev DK (1979) Destabilizing selection as a factor in domestication. Journal of Heredity 70(5):301-308.

25. Guagnin M, Perri AR, \& Petraglia MD (2018) Pre-Neolithic evidence for dog-assisted hunting strategies in Arabia. Journal of Anthropological Archaeology 49:225-236.

26. Morey DF (2006) Burying key evidence: the social bond between dogs and people. Journal of Archaeological Science 33(2):158-175.

27. Clutton-Brock J (2016) Origins of the dog: The archaeological evidence. The Domestic Dog: Its Evolution, Behavior and Interactions with People, ed Serpell J (Cambridge University Press, Cambridge, United Kingdom), pp 7-21.

28. Jensen P (2010) Domestication, selection, behaviour and welfare of animals-genetic mechanisms for rapid responses. Animal Welfare 19(2):7-9. 
29. Agnvall B, Bélteky J, Katajamaa R, \& Jensen P (2018) Is evolution of domestication driven by tameness? A selective review with focus on chickens. Applied Animal Behaviour Science 205:227-233.

30. Trut L, Oskina I, \& Kharlamova A (2009) Animal evolution during domestication: the domesticated fox as a model. Bioessays 31(3):349-360.

31. Albert FW, et al. (2008) Phenotypic differences in behavior, physiology and neurochemistry between rats selected for tameness and for defensive aggression towards humans. Hormones and Behavior 53(3):413-421.

32. Wilkins AS, Wrangham RW, \& Fitch WT (2014) The "domestication syndrome" in mammals: a unified explanation based on neural crest cell behavior and genetics. Genetics 197(3):795-808.

33. Sundqvist A-K, et al. (2006) Unequal contribution of sexes in the origin of dog breeds. Genetics 172(2):1121-1128.

34. Parker HG, et al. (2004) Genetic structure of the purebred domestic dog. Science 304.

35. Parker HG, et al. (2017) Genomic analyses reveal the influence of geographic origin, migration, and hybridization on modern dog breed development. Cell reports 19(4):697-708.

36. Quignon P, et al. (2007) Canine Population Structure: Assessment and Impact of IntraBreed Stratification on SNP-Based Association Studies. PLoS ONE 2(12).

37. Arnott ER, et al. (2015) Strong selection for behavioural resilience in Australian stock working dogs identified by selective sweep analysis. Canine Genetics and Epidemiology 2(1):6.

38. Lindblad-Toh K (2005) Genome sequence, comparative analysis and haplotype structure of the domestic dog. Nature 438:803-819.

39. Boyko AR (2011) The domestic dog: man's best friend in the genomic era. Genome Biology 12(2).

40. Hoopes BC, Rimbault M, Liebers D, Ostrander EA, \& Sutter NB (2012) The insulinlike growth factor 1 receptor (IGF1R) contributes to reduced size in dogs. Mammalian Genome 23(11-12):780-790.

41. Kaelin CB \& Barsh GS (2013) Genetics of pigmentation in dogs and cats. Annu Rev Anim Biosci 1:125-156.
42. Cadieu E, et al. (2009) Coat variation in the domestic dog is governed by variants in three genes. Science 326.

43. Miklósi Á \& Topál J (2013) What does it take to become 'best friends'? Evolutionary changes in canine social competence. Trends Cogn Sci 17(6):287-294.

44. Miklósi A, Polgárdi R, Topál J, \& Csányi V (2000) Intentional behaviour in dog-human communication: an experimental analysis of "showing" behaviour in the dog. Animal Cognition 3(3):159-166.

45. Kaminski J, Schulz L, \& Tomasello M (2012) How dogs know when communication is intended for them. Developmental Science 15(2):222-232.

46. Nagasawa M, et al. (2015) Oxytocin-gaze positive loop and the coevolution of humandog bonds. Science 348(6232):333-336.

47. Johnston AM, Turrin C, Watson L, Arre AM, \& Santos LR (2017) Uncovering the origins of dog-human eye contact: dingoes establish eye contact more than wolves, but less than dogs. Animal Behaviour 133:123-129.

48. Gácsi M, et al. (2005) Species-specific differences and similarities in the behavior of hand-raised dog and wolf pups in social situations with humans. Developmental Psychobiology: The Journal of the International Society for Developmental Psychobiology 47(2):111-122.

49. Romero T, Nagasawa M, Mogi K, Hasegawa T, \& Kikusui T (2014) Oxytocin promotes social bonding in dogs. Proceedings of the National Academy of Sciences 111(25):9085-9090.

50. Handlin L, et al. (2011) Short-term interaction between dogs and their owners: effects on oxytocin, cortisol, insulin and heart rate-an exploratory study. Anthrozoös 24(3):301-315.

51. Topál J, Miklósi Á, Csányi V, \& Dóka A (1998) Attachment behavior in dogs (Canis familiaris): a new application of Ainsworth's (1969) Strange Situation Test. Journal of Comparative Psychology 112(3):219.

52. Topál J, et al. (2005) Attachment to humans: a comparative study on hand-reared wolves and differently socialized dog puppies. Animal Behaviour 70(6):1367-1375.

53. Liszkowski U, Brown P, Callaghan T, Takada A, \& De Vos C (2012) A prelinguistic gestural 
universal of human communication. Cognitive Science 36(4):698-713.

54. Hare B, Call J, \& Tomasello M (1998) Communication of food location between human and dog (Canis familiaris). Evolution of Communication 2(1):137-159.

55. Miklósi Á, Polgárdi R, Topál J, \& Csányi V (1998) Use of experimenter-given cues in dogs. Animal Cognition 1(2):113-121.

56. Lakatos G, Soproni K, Dóka A, \& Miklósi Á (2009) A comparative approach to dogs'(Canis familiaris) and human infants' comprehension of various forms of pointing gestures. Animal Cognition 12(4):621-631.

57. Soproni K, Miklósi Á, Topál J, \& Csányi V (2002) Dogs'(Canis familaris) responsiveness to human pointing gestures. Journal of Comparative Psychology 116(1):27.

58. McKinley J \& Sambrook TD (2000) Use of human-given cues by domestic dogs (Canis familiaris) and horses (Equus caballus). Animal Cognition 3(1):13-22.

59. Gácsi M, Kara E, Belényi B, Topál J, \& Miklósi Á (2009) The effect of development and individual differences in pointing comprehension of dogs. Animal Cognition 12(3):471-479.

60. Riedel J, Schumann K, Kaminski J, Call J, \& Tomasello M (2008) The early ontogeny of human-dog communication. Animal Behaviour 75(3):1003-1014.

61. Tauzin T, Csík A, Kis A, \& Topál J (2015) What or where? The meaning of referential human pointing for dogs (Canis familiaris). Journal of Comparative Psychology 129(4):334.

62. Hare B, Brown M, Williamson C, \& Tomasello M (2002) The domestication of social cognition in dogs. Science 298(5598):1634-1636.

63. Call J, Agnetta B, \& Tomasello M (2000) Cues that chimpanzees do and do not use to find hidden objects. Animal Cognition 3(1):23-34.

64. Kirchhofer KC, Zimmermann F, Kaminski J, \& Tomasello M (2012) Dogs (Canis familiaris), but not chimpanzees (Pan troglodytes), understand imperative pointing. PLOS ONE 7(2):e30913.

65. Virányi Z, et al. (2008) Comprehension of human pointing gestures in young humanreared wolves (Canis lupus) and dogs (Canis familiaris). Animal Cognition 11(3):373-387.
66. Lampe M, Bräuer J, Kaminski J, \& Virányi Z (2017) The effects of domestication and ontogeny on cognition in dogs and wolves. Scientific Reports 7(1):11690.

67. Udell MA, Spencer JM, Dorey NR, \& Wynne CD (2012) Human-socialized wolves follow diverse human gestures... and they may not be alone. International Journal of Comparative Psychology 25(2).

68. Miklósi Á \& Soproni K (2006) A comparative analysis of animals' understanding of the human pointing gesture. Animal Cognition 9(2):81-93.

69. Worsley HK \& O'Hara SJ (2018) Cross-species referential signalling events in domestic dogs (Canis familiaris). Animal Cognition 21:457465.

70. Virányi Z, Topál J, Miklósi Á, \& Csányi V (2006) A nonverbal test of knowledge attribution: a comparative study on dogs and children. Animal Cognition 9(1):13-26.

71. Marshall-Pescini S, Colombo E, Passalacqua C, Merola I, \& Prato-Previde E (2013) Gaze alternation in dogs and toddlers in an unsolvable task: evidence of an audience effect. Animal Cognition 16(6):933-943.

72. Miklósi Á, et al. (2003) A simple reason for a big difference: wolves do not look back at humans, but dogs do. Current Biology 13(9):763-766.

73. Udell MA (2015) When dogs look back: inhibition of independent problem-solving behaviour in domestic dogs (Canis lupus familiaris) compared with wolves (Canis lupus). Biology Letters 11(9):20150489.

74. Brubaker L, Dasgupta S, Bhattacharjee D, Bhadra A, \& Udell MAR (2017) Differences in problem-solving between canid populations: Do domestication and lifetime experience affect persistence? Animal Cognition 20(4):717723.

75. Marshall-Pescini S, Rao A, Virányi Z, \& Range F (2017) The role of domestication and experience in 'looking back'towards humans in an unsolvable task. Scientific Reports 7.

76. Rao A, Bernasconi L, Lazzaroni M, MarshallPescini S, \& Range F (2018) Differences in persistence between dogs and wolves in an unsolvable task in the absence of humans. PeerJ 6:e5944. 
77. Persson ME, Roth LS, Johnsson M, Wright D, \& Jensen P (2015) Human-directed social behaviour in dogs shows significant heritability. Genes, Brain, and Behavior 14(4):337-344

78. MacLean EL, Herrmann E, Suchindran S, \& Hare B (2017) Individual differences in cooperative communicative skills are more similar between dogs and humans than chimpanzees. Animal Behaviour 126:41-51.

79. Topál J, Gergely G, Erdőhegyi Á, Csibra G, \& Miklósi Á (2009) Differential sensitivity to human communication in dogs, wolves, and human infants. Science 325(5945):1269-1272.

80. Hare B \& Tomasello M (2005) Human-like social skills in dogs? Trends in Cognitive Sciences 9(9):439-444.

81. Udell MA, Dorey NR, \& Wynne CD (2010) What did domestication do to dogs? A new account of dogs' sensitivity to human actions. Biological reviews 85(2):327-345.

82. Freedman DG, King JA, \& Elliot O (1961) Critical period in the social development of dogs. Science 133(3457):1016-1017.

83. Smith BP \& Litchfield CA (2010) Dingoes (Canis dingo) can use human social cues to locate hidden food. Animal Cognition 13(2):367-376.

84. Range F \& Virányi Z (2015) Tracking the evolutionary origins of dog-human cooperation: the "Canine Cooperation Hypothesis". Frontiers in Psychology 5:1582.

85. Range F \& Virányi Z (2016) Social cognition and emotions underlying dog behavior. The Domestic Dog: Its Evolution, Behavior and Interactions with People, ed Serpell J (Cambridge University Press, Cambridge), 2 Ed, pp 182-209.

86. Mehrkam LR \& Wynne CDL (2014) Behavioral differences among breeds of domestic dogs (Canis lupus familiaris): Current status of the science. Applied Animal Behaviour Science.

87. Arvelius P, Malm S, Svartberg K, \& Strandberg E (2013) Measuring herding behavior in Border collie-effect of protocol structure on usefulness for selection. Journal of Veterinary Behavior-Clinical Applications and Research 8(1):9-18.

88. Brodd L (2016) Behavioural differences between and within retriever breeds.
Independent thesis Advanced level (degree of Master (Two Years)) Student thesis). Linköping university. Supervisors: Per Jensen and Ann-Sofie Sundman

89. Fratkin JL, Sinn DL, Patall EA, \& Gosling SD (2013) Personality Consistency in Dogs: A Meta-Analysis. PLoS ONE 8(1):e54907.

90. Svartberg K, Tapper I, Temrin H, Radesater T, \& Thorman S (2005) Consistency of personality traits in dogs. Animal Behaviour 69:283-291.

91. Hart BL \& Hart LA (2016) Breed and gender differences in dog behavior. The Domestic Dog: Its Evolution, Behavior and Interactions with People, ed Serpell J (Cambridge University Press, Cambridge), 2 Ed, pp 118-132.

92. Serpell JA \& Duffy DL (2014) Dog Breeds and Their Behavior. Domestic Dog Cognition and Behavior: The Scientific Study of Canis familiaris, ed Horowitz A (Springer Berlin Heidelberg, Berlin, Heidelberg), pp 31-57.

93. Svartberg K \& Forkman B (2002) Personality traits in the domestic dog (Canis familiaris). Applied Animal Behaviour Science 79(2):133-155.

94. Svartberg K (2005) A comparison of behaviour in test and in everyday life: evidence of three consistent boldness-related personality traits in dogs. Applied Animal Behaviour Science 91(1-2):103-128.

95. Svartberg K (2002) Shyness-boldness predicts performance in working dogs. Applied Animal Behaviour Science 79(2):157-174.

96. Svartberg K (2006) Breed-typical behaviour in dogs - Historical remnants or recent constructs? Applied Animal Behaviour Science 96(3-4):293-313.

97. Jones AC (2008) Development and validation of a dog personality questionnaire. PhD (The University of Texas at Austin).

98. Hsu YY \& Serpell JA (2003) Development and validation of a questionnaire for measuring behavior and temperament traits in pet dogs. Journal of the American Veterinary Medical Association 223(9):1293-+.

99. Lofgren SE, et al. (2014) Management and personality in Labrador Retriever dogs. Applied Animal Behaviour Science 156:44-53.

100. Serpell JA \& Hsu YY (2005) Effects of breed, sex, and neuter status on trainability in dogs. Anthrozoös 18(3):196-207. 
101. Duffy DL, Hsu YY, \& Serpell JA (2008) Breed differences in canine aggression. Applied Animal Behaviour Science 114(3-4):441-460.

102. Turcsán B, Kubinyi E, \& Miklósi Á (2011) Trainability and boldness traits differ between dog breed clusters based on conventional breed categories and genetic relatedness. Applied Animal Behaviour Science 132(1-2):6170.

103. Wobber V, Hare B, Koler-Matznick J, Wrangham R, \& Tomasello M (2009) Breed differences in domestic dogs'(Canis familiaris) comprehension of human communicative signals. Interaction Studies 10(2):206-224.

104. Gácsi M, McGreevy P, Kara E, \& Miklósi Á (2009) Effects of selection for cooperation and attention in dogs. Behav Brain Funct 5(1):31.

105. Udell MAR, Ewald M, Dorey NR, \& Wynne CDL (2014) Exploring breed differences in dogs (Canis familiaris): does exaggeration or inhibition of predatory response predict performance on human-guided tasks? Animal Behaviour 89:99-105.

106. Jakovcevic A, Elgier AM, Mustaca AE, \& Bentosela M (2010) Breed differences in dogs' (Canis familiaris) gaze to the human face. Behavioural Processes 84(2):602-607.

107. Horschler DJ, et al. (2019) Absolute brain size predicts dog breed differences in executive function. Animal Cognition:1-12.

108. Stone HR, McGreevy PD, Starling MJ, \& Forkman B (2016) Associations between domestic-dog morphology and behaviour scores in the dog mentality assessment. PLoS ONE 11(2):e0149403.

109. Rooney NJ (2009) The welfare of pedigree dogs: Cause for concern. Journal of Veterinary Behavior: Clinical Applications and Research 4(5):180-186.

110. McGreevy P, Grassi TD, \& Harman AM (2004) A strong correlation exists between the distribution of retinal ganglion cells and nose length in the dog. Brain, Behavior and Evolution 63(1):13-22.

111. Lind O, Milton I, Andersson E, Jensen P, \& Roth LS (2017) High visual acuity revealed in dogs. PLoS ONE 12(12):e0188557.

112. Jensen $P$ (2018) 2 - Genetics and genomics of animal welfare. Advances in Agricultural Animal Welfare, ed Mench JA (Woodhead Publishing), pp 25-48.
113. Scott J (1964) Genetics and the development of social behavior in dogs. American Zoologist:161-168.

114. Axelsson E, et al. (2013) The genomic signature of dog domestication reveals adaptation to a starch-rich diet. Nature 495(7441):360.

115. Arvelius P, Asp HE, Fikse WF, Strandberg E, \& Nilsson K (2014) Genetic analysis of a temperament test as a tool to select against everyday life fearfulness in Rough Collie. Journal of Animal Science 92(11):4843-4855.

116. Saetre $P$, et al. (2006) The genetic contribution to canine personality. Genes, Brain, and Behavior 5(3):240-248.

117. Strandberg E, Jacobsson J, \& Saetre P (2005) Direct genetic, maternal and litter effects on behaviour in German shepherd dogs in Sweden. Livestock Production Science 93(1):3342.

118. Visscher PM, Hill WG, \& Wray NR (2008) Heritability in the genomics era-concepts and misconceptions. Nature Reviews Genetics 9(4):255-266.

119. Hradecká L, Bartoš L, Svobodová I, \& Sales J (2015) Heritability of behavioural traits in domestic dogs: A meta-analysis. Applied Animal Behaviour Science.

120. Persson ME, Wright D, Roth LS, Batakis P, \& Jensen P (2016) Genomic regions associated with interspecies communication in dogs contain genes related to human social disorders. Scientific Reports 6.

121. Chapman NH, et al. (2015) Whole exome sequencing in extended families with autism spectrum disorder implicates four candidate genes. Human Genetics 134(10):1055-1068.

122. Qayyum A, et al. (2015) The role of the catechol-o-methyltransferase (COMT) geneval158met in aggressive behavior, a review of genetic studies. Current Neuropharmacology 13(6):802-814.

123. Sanders AR, et al. (2004) Haplotypic association spanning the 22q11.21 genes COMT and ARVCF with schizophrenia. Molecular Psychiatry 10:353.

124. Luo D, et al. (2018) Association between COMT SNP variation and timidity in Golden and Labrador Retrievers. Animal Genetics 49(4):340-344. 
125. Takeuchi Y, et al. (2009) An approach to canine behavioural genetics employing guide dogs for the blind. Animal Genetics 40(2):217224.

126. vonHoldt BM, et al. (2017) Structural variants in genes associated with human WilliamsBeuren syndrome underlie stereotypical hypersociability in domestic dogs. Science Advances 3(7):e1700398.

127. Li HH, et al. (2009) Induced chromosome deletions cause hypersociability and other features of Williams-Beuren syndrome in mice. EMBO Molecular Medicine 1(1):50-65.

128. Doyle TF, Bellugi U, Korenberg JR, \& Graham $\mathrm{J}$ (2004) "Everybody in the world is my friend" hypersociability in young children with Williams syndrome. American Journal of Medical Genetics Part A 124(3):263-273.

129. Janowitz Koch I, et al. (2016) The concerted impact of domestication and transposon insertions on methylation patterns between dogs and grey wolves. Molecular Ecology 25(8):1838-1855.

130. Kis A, et al. (2014) Oxytocin Receptor Gene Polymorphisms Are Associated with Human Directed Social Behavior in Dogs (Canis familiaris). PLOS ONE 9(1).

131. Persson ME, Trottier AJ, Bélteky J, Roth LS, \& Jensen P (2017) Intranasal oxytocin and a polymorphism in the oxytocin receptor gene are associated with human-directed social behavior in golden retriever dogs. Hormones and Behavior 95:85-93.

132. Kubinyi E, et al. (2017) Oxytocin and opioid receptor gene polymorphisms associated with greeting behavior in dogs. Frontiers in Psychology 8:1520.

133. Våge J, et al. (2010) Association of dopamineand serotonin-related genes with canine aggression. Genes, Brain, and Behavior 9(4):372378.

134. Ilska J, et al. (2017) Genetic Characterisation of Dog Personality Traits. Genetics.

135. Sarviaho R, et al. (2019) Two novel genomic regions associated with fearfulness in dogs overlap human neuropsychiatric loci. Translational psychiatry 9(1):18.
136. Konno A, Inoue-Murayama M, \& Hasegawa T (2011) Androgen receptor gene polymorphisms are associated with aggression in Japanese Akita Inu. Biology Letters 7(5):658-660.

137. Ericsson M, et al. (2016) Long-term and transgenerational effects of stress experienced during different life phases in chickens (Gallus gallus). PLoS ONE 11(4):e0153879.

138. Foyer P, Wilsson E, \& Jensen P (2016) Levels of maternal care in dogs affect adult offspring temperament. Scientific Reports 6:19253.

139. Bray EE, Sammel MD, Cheney DL, Serpell JA, \& Seyfarth RM (2017) Effects of maternal investment, temperament, and cognition on guide dog success. Proceedings of the National Academy of Sciences 114(34):9128-9133.

140. Foyer P, Wilsson E, Wright D, \& Jensen P (2013) Early experiences modulate stress coping in a population of German shepherd dogs. Applied Animal Behaviour Science 146(14):79-87.

141. Fox M \& Stelzner D (1966) Behavioural effects of differential early experience in the dog. Animal Behaviour 14(2-3):273-281.

142. Gazzano A, Mariti C, Notari L, Sighieri C, \& McBride EA (2008) Effects of early gentling and early environment on emotional development of puppies. Applied Animal Behaviour Science 110(3-4):294-304.

143. McMillan FD, Serpell JA, Duffy DL, Masaoud E, \& Dohoo IR (2013) Differences in behavioral characteristics between dogs obtained as puppies from pet stores and those obtained from noncommercial breeders. Journal of the American Veterinary Medical Association 242(10):1359-1363.

144. D'Aniello B, et al. (2017) What's the point? Golden and Labrador retrievers living in kennels do not understand human pointing gestures. Animal Cognition 20(4):777-787.

145. D'Aniello B \& Scandurra A (2016) Ontogenetic effects on gazing behaviour: a case study of kennel dogs (Labrador Retrievers) in the impossible task paradigm. Animal Cognition 19(3):565-570.

146. Marshall-Pescini S, Passalacqua C, Barnard S, Valsecchi P, \& Prato-Previde E (2009) Agility and search and rescue training differently affects pet dogs' behaviour in socio-cognitive tasks. Behavioural Processes 81(3):416-422. 
147. Dodman NH, Brown DC, \& Serpell JA (2018) Associations between owner personality and psychological status and the prevalence of canine behavior problems. PLOS ONE 13(2):e0192846.

148. Rehn T, Beetz A, \& Keeling LJ (2017) Links between an owner's adult attachment style and the support-seeking behavior of their dog. Frontiers in Psychology 8:2059.

149. Cimarelli G, Turcsán B, Bánlaki Z, Range F, \& Virányi Z (2016) Dog Owners' Interaction Styles: Their Components and Associations with Reactions of Pet Dogs to a Social Threat. Frontiers in Psychology 7(1979).

150. Kis A, Turcsán B, Miklósi Á, \& Gácsi M (2012) The effect of the owner's personality on the behaviour of owner-dog dyads. Interaction Studies 13(3):373-385.

151. Duranton C \& Gaunet F (2016) Behavioural synchronization from an ethological perspective: overview of its adaptive value. Adaptive Behavior 24(3):181-191.

152. Duranton C, Bedossa T, \& Gaunet F (2018) Pet dogs synchronize their walking pace with that of their owners in open outdoor areas. Animal Cognition 21(2):219-226.

153. Duranton C, Bedossa T, \& Gaunet F (2017) Interspecific behavioural synchronization: dogs exhibit locomotor synchrony with humans. Scientific Reports 7(1):12384.

154. Duranton C, Bedossa T, \& Gaunet F (2019) Pet dogs exhibit social preference for people who synchronize with them: what does it tell us about the evolution of behavioral synchronization? Animal Cognition:1-8.

155. Merola I, Prato-Previde E, \& Marshall-Pescini $S$ (2012) Social referencing in dog-owner dyads? Animal Cognition 15(2):175-185.

156. Fugazza C, Moesta A, Pogány Á, \& Miklósi Á (2018) Presence and lasting effect of social referencing in dog puppies. Animal Behaviour 141:67-75.

157. Heimbürge S, Kanitz E, \& Otten W (2018) The use of hair cortisol for the assessment of stress in animals. General and Comparative Endocrinology.

158. Roth LSV, Faresjö Å, Theodorsson E, \& Jensen P (2016) Hair cortisol varies with season and lifestyle and relates to human interactions in German shepherd dogs. Scientific Reports 6:19631.
159. Shiverdecker MD, Schiml PA, \& Hennessy MB (2013) Human interaction moderates plasma cortisol and behavioral responses of dogs to shelter housing. Physiology \& Behavior 109:75-79.

160. Polheber JP \& Matchock RL (2014) The presence of a dog attenuates cortisol and heart rate in the Trier Social Stress Test compared to human friends. Journal of Behavioral Medicine 37(5):860-867.

161. Kotrschal K \& Ortbauer B (2003) Behavioral effects of the presence of a dog in a classroom. Anthrozoös 16(2):147-159.

162. de Waal FB (2008) Putting the altruism back into altruism: the evolution of empathy. Annual Review of Psychology 59:279-300.

163. Burkett JP, et al. (2016) Oxytocin-dependent consolation behavior in rodents. Science 351(6271):375-378.

164. Buttner AP, Thompson B, Strasser R, \& Santo J (2015) Evidence for a synchronization of hormonal states between humans and dogs during competition. Physiology \& Behavior 147:54-62.

165. Sümegi Z, Oláh K, \& Topál J (2014) Emotional contagion in dogs as measured by change in cognitive task performance. Applied Animal Behaviour Science 160:106-115.

166. Schloss S, et al. (2018) Hair cortisol concentration in mothers and their children: roles of maternal sensitivity and child symptoms of attention-deficit/hyperactivity disorder. J Neural Transm (Vienna).

167. Ouellette SJ, et al. (2015) Hair cortisol concentrations in higher- and lower-stress mother-daughter dyads: A pilot study of associations and moderators. Developmental Psychobiology 57(5):519-534.

168. De Palma C, et al. (2005) Evaluating the temperament in shelter dogs. Behaviour 142(910):1307-1328.

169. Schöberl I, Wedl M, Beetz A, \& Kotrschal K (2017) Psychobiological Factors Affecting Cortisol Variability in Human-Dog Dyads. PLoS ONE 12(2):e0170707.

170. Ottenheimer Carrier L, Cyr A, Anderson RE, \& Walsh CJ (2013) Exploring the dog park: Relationships between social behaviours, personality and cortisol in companion dogs. Applied Animal Behaviour Science 146(1):96-106. 
171. Kotrschal K, Schöberl I, Bauer B, Thibeaut AM, \& Wedl M (2009) Dyadic relationships and operational performance of male and female owners and their male dogs. Behavioural Processes 81(3):383-391.

172. Marshall-Pescini S, Frazzi C, \& Valsecchi P (2016) The effect of training and breed group on problem-solving behaviours in dogs. Animal Cognition 19(3):571-579.

173. Gosling SD, Sandy CJ, \& Potter J (2010) Personalities of Self-Identified "Dog People" and "Cat People". Anthrozoös 23(3):213-222.

174. Wu C \& Morris JR (2001) Genes, genetics, and epigenetics: a correspondence. Science 293(5532):1103-1105.

175. Bird A (2007) Perceptions of epigenetics. Nature 447:396.

176. Jensen P (2014) Behaviour epigenetics-the connection between environment, stress and welfare. Applied Animal Behaviour Science 157:1-7.

177. Liu D, et al. (1997) Maternal care, hippocampal glucocorticoid receptors, and hypothalamic-pituitary-adrenal responses to stress. Science 277(5332):1659-1662.

178. Weaver IC, et al. (2004) Epigenetic programming by maternal behavior. Nature Neuroscience 7(8):847.

179. Serpeloni F, et al. (2017) Grandmaternal stress during pregnancy and DNA methylation of the third generation: an epigenome-wide association study. Translational psychiatry 7:e1202.

180. Cimarelli G, et al. (2017) Social behavior of pet dogs is associated with peripheral OXTR methylation. Frontiers in Psychology 8:549.

181. Skinner MK (2015) Environmental epigenetics and a unified theory of the molecular aspects of evolution: a neo-Lamarckian concept that facilitates neo-Darwinian evolution. Genome Biology and Evolution 7(5):1296-1302.

182. Jensen P (2015) Adding 'epi-'to behaviour genetics: implications for animal domestication. Journal of Experimental Biology 218(1):32-40.

183. Jablonka E (2017) The evolutionary implications of epigenetic inheritance. Interface focus 7(5):20160135.
184. Dolinoy DC, Huang D, \& Jirtle RL (2007) Maternal nutrient supplementation counteracts bisphenol A-induced DNA hypomethylation in early development. Proceedings of the National Academy of Sciences 104(32):13056-13061.

185. Guerrero-Bosagna C, Settles M, Lucker B, \& Skinner MK (2010) Epigenetic transgenerational actions of vinclozolin on promoter regions of the sperm epigenome. PLOS ONE 5(9):e13100.

186. Nätt D, et al. (2009) Inheritance of acquired behaviour adaptations and brain gene expression in chickens. PLoS ONE 4(7):e6405.

187. Skinner MK, Guerrero-Bosagna C, \& Haque MM (2015) Environmentally induced epigenetic transgenerational inheritance of sperm epimutations promote genetic mutations. Epigenetics 10(8):762-771.

188. Saetre P, et al. (2004) From wild wolf to domestic dog: gene expression changes in the brain. Molecular brain research 126(2):198-206.

189. Albert FW, et al. (2012) A comparison of brain gene expression levels in domesticated and wild animals.

190. Nätt D, et al. (2012) Heritable genome-wide variation of gene expression and promoter methylation between wild and domesticated chickens. BMC Genomics 13(1):59.

191. Banlaki Z, et al. (2017) DNA methylation patterns of behavior-related gene promoter regions dissect the gray wolf from domestic dog breeds. Molecular Genetics and Genomics 292(3):685-697.

192. Jones PA \& Takai D (2001) The role of DNA methylation in mammalian epigenetics. Science 293(5532):1068-1070.

193. Davis AP, Witte DP, Hsieh-Li HM, Potter SS, \& Capecchi MR (1995) Absence of radius and ulna in mice lacking hoxa-11 andhoxd-11. Nature 375(6534):791.

194. Brocal J, et al. (2018) C7 vertebra homeotic transformation in domestic dogs-are Pug dogs breaking mammalian evolutionary constraints? Journal of Anatomy 233(2):255-265.

195. Sutter NB, et al. (2007) A single IGF1 allele is a major determinant of small size in dogs. Science 316(5821):112-115.

196. Zapata I, Serpell JA, \& Alvarez CE (2016) Genetic mapping of canine fear and aggression. BMC Genomics 17(1):572. 



\section{Papers}

The papers associated with this thesis have been removed for copyright reasons. For more details about these see:

http://urn.kb.se/resolve?urn=urn:nbn:se:liu:diva-156353 


\section{Avhandlingar från Biologi och Teoretisk Biologi Avdelningar}

01. Wennergren, Uno. Population growth and structure in a variable environment. Dissertation No. 293. Datum 15/01/1993. Ämnesområde Teoretisk biologi

02. Jonsson, Tomas. Food webs and the distribution of body sizes. Dissertation No. 535. Datum 15/05/1998. Ämnesområde Teoretisk biologi

03. Bergman, Karl-Olof. Ecology and conservation of the butterfly Lopinga achine. Dissertation No. 621. Datum 27/03/2000. Ämnesområde Biologi

04. Jonsson, Annie. Life histories and population dynamics. Dissertation No. 656. Datum 20/10/2000. Ämnesområde Teoretisk biologi

05. Hermansson, Anna. Ammonia-Oxidising Bacteria in Soil. Dissertation No. 712. Datum 28/09/2001. Ämnesområde Mikrobiologi

06. Öquist, Mats. Northern peatland carbon biogeochemistry. The influence of vascular plants and edaphic factors on carbon dioxide and methane exchange. Dissertation No. 729. Datum 14/12/2001. Ämnesområde Biologi

07. Lundqvist, Elisabeth. Diversity, dispersal, and interactions among diving beetles and mosquitoes in Swedish wetlands. Dissertation No. 796. Datum 21/03/2003. Ämnesområde Ekologi

08. Bäckman, Jenny. Nitrification and nitrifying bacterial communities in coniferous forest soils. Effects of liming and clear-cutting. Dissertation No. 809. Datum 23/05/2003. Ämnesområde Mikrobiologi

09. Ebenå, Gustav. Sulfidic mine waste microorganisms in an ecological context. Dissertation No. 841. Datum 26/09/2003. Ämnesområde Biologi

10. Westerberg, Lars. Population processes in heterogeneous landscapes. Dissertation No. 897. Datum 15/10/2004. Ämnesområde Teoretisk biologi

11. Blomqvist, Christer. Directional aggressive pulse sounds in the Bottlenose dolphin (Tursiops truncatus): technical aspects and social implications. Dissertation No. 905. Datum 17/12/2004. Ämnesområde Zoologi

12. Väisänen, Johanna. Characterisation of social behaviour in Red Junglefowl and White Leghorn laying hens - Phenotypic and genetic studies. Dissertation No. 970. Datum 19/10/2005. Ämnesområde Etologi

13. Christianou, Maria. Interaction strength and responses of ecological communities to disturbances. Dissertation No.1002. Datum 03/03/2006. Ämnesområde Teoretisk biologi

14. Fjälling, Arne. The conflict between grey seals (Halichoerus grypus) and the Baltic coastal fisheries. Dissertation No.1006. Datum 10/03/2006. Ämnesområde Zoologi

15. Borrvall, Charlotte. Biodiversity and species extinction in model food webs. Dissertation No.1015. Datum 19/05/2006. Ämnesområde Teoretisk biologi

16. Bastviken, Sofia. Nitrogen removal in treatment wetlands - factors influencing spatial and temporal variations. Dissertation No.1041. Datum 10/11/2006. Ämnesområde Ekologi

17. Karlsson, Laila. Seed dormancy and germination in an ecological context. Comparative studies of annual weeds. Dissertation No.1088. Datum 17/04/2007. Ämnesområde Ekologi 
18. Håkansson, Jennie. Behavioural aspects of conservation breeding. Red Junglefowl (Gallus gallus) as a case study. Dissertation No.1137. Datum 23/11/2007. Ämnesområde Etologi

19. Lundkvist, Christina. Domestication effects on foraging behaviour - consequences for adaptability in chickens. Dissertation No. 1164. Datum 28/03/2008. Ämnesområde Etologi

20. Lundin, Björn. Nucleotide-dependent processes in the thylakoid lumen of plant chloroplasts. Dissertation No. 1165. Datum 04/04/2008. Ämnesområde Genetik

21. Bergstedt, Johan. Boreal vegetation responses to forestry as reflected in field trial and survey data and the quality of cover estimates and presence/absence in vegetation inventory. Dissertation No. 1172. Datum 25/04/2008. Ämnesområde Ekologi

22. Jansson, Nicklas. Habitat requirements and preservation of the beetle asseblages associated with hollow oaks. Dissertation No. 1246. Datum 05/06/2009. Ämnesområde Ekologi

23. Eklöf, Anna. Species extinctions in food webs - local and regional processes. Dissertation No 1291. Datum 18/12/2009. Ämnesområde Teoretisk biologi

24. Lindström, Tom. Spatial spread of organisms. Modeling ecological and epidemiological processes. Dissertation No 1311. Datum 07/05/2010. Ämnesområde Teoretisk biologi

25. Lindgren, Isa. Cardiovascular $\beta$-adrenergic signaling. Maturation and programming effects of hypoxia in a chicken model. Dissertation No. 1330. Datum 10/09/2010. Ämnesområde Zoologi

26. Nätt, Daniel. Heritable epigenic responses to environmental challenges. Effects on behaviour, gene expression and DNA-methylation in the chicken. Dissertation No. 1383. Datum 16/09/2011. Ämnesområde Etologi

27. Lögdberg, Frida. Population dynamics in variable environments - impacts of noise colour and synchrony. Dissertation No. 1416. Datum 13/01/2012. Ämnesområde Teoretisk biologi

28. Wirén, Anders. Correlated selection responses in animal domestication: the behavioral effects of a growth QTL in chickens. Dissertation No. 1413. Datum 20/01/2012. Ämnesområde Etologi

29. Kaneryd, Linda. Dynamics of ecological communities in variable environments - local and spatial processes. Dissertation No. 1431. Datum 04/04/2012. Ämnesområde Teoretisk biologi

30. Håkansson, Nina. Network analysis and optimization of animal transports. Dissertation No. 1434. Datum 26/04/2012. Ämnesområde Teoretisk biologi

31. Lennartsson, Jenny. Networks and epedemics - impact of network structure on disease transmission. Dissertation No. 1433. Datum 27/04/2012. Ämnesområde Teoretisk biologi

32. Setzer, Malin. The decline of great Arctic charr in Lake Vättern - empirical and theoretical analyses of suggested causes. Dissertation No. 1447. Datum 01/06/2012. Ämnesområde Teoretisk biologi

33. Lättman, Håkan. Studies on spatial and temporal distributions of epiphytic lichens. Dissertation No. 1471. Datum 22/10/2012. Ämnesområde Ekologi

34. Berg, Sofia. Community Bobustness Analysis: Theoretical Approaches to Identifying Keystone Structures in Ecological Communities. Dissertation No. 1498. Datum 15/02/2013. Ämnesområde Teoretisk biologi 
35. Bodin, Hristina. Wastewater treatment in constructed wetlands. Effects of vegetation, hydraulics and data analysis methods. Dissertation No. 1509. Datum 30/05/2013. Ämnesområde Ekologi

36. Edstam, Monika. Plant lipid transfer proteins - Evolution, expression and function. Dissertation No. 1525. Datum 22/10/2013. Ämnesområde Genetik

37. Curtsdotter, Alva. Extinctions in ecological communities - direct and indirect effects of perturbation on biodiversity. Dissertation No. 1609. Datum 29/08/2014. Ämnesområde Teoretisk biologi

38. Karlsson, Anna-Carin. Effects of domestication related genes on behaviour, physiology and gene expression in chickens. Dissertation No. 1633. Datum 16/01/2015. Ämnesområde Etologi

39. Johannesson, Karin. Particulate phosphorus accumulation and net retention in constructed wetlands receiving agricultural runoff. Dissertation No.1648. Datum 29/05/2015. Ämnesområde Ekologi

40. Elfwing, Magnus. The physiology of chicken domestication: involvement of the HPA-axis and the Autonomic Nervous System. Dissertation No.1651. Datum 05/06/2015. Ämnesområde Biologi m inr zoologi

41. Foyer, Pernilla. Early experience, maternal care and behavioural test design. Effects on the temperament of military working dogs. Dissertation No. 1703. Datum 11/12/2015. Ämnesområde Etologi

42. Johnsson, Martin. Genomics of chicken domestication and feralisation. Dissertation No. 1708. Datum 18/12/2015. Ämnesområde Genetik

43. Gilljam, David. Structure and stability of ecological networks. The role of dynamic dimensionality and species variability in resource use. Dissertation No. 1735. Datum 12/02/2016. Ämnesområde Teoretisk biologi

44. Säterberg, Torbjörn. Functional extinctions of species in ecological networks. Dissertation No. 1757. Datum 20/05/2016. Ämnesområde Teoretisk biologi

45. Ericsson, Maria. Stress in chickens: effects of domestication and early experience on behaviour and welfare. Dissertation No. 1755. Datum 03/06/2016. Ämnesområde Etologi

46. Agnvall, Beatrix. Early domestication? Phenotypic alterations of Red Junglefowl selected for divergent fear of humans. Dissertation No. 1790. Datum 07/12/2016. Ämnesområde Etologi

47. Bélteky, Johan. Chicken domestication. Effects of tameness on gene expression and gene methylation. Dissertation No. 1796. Datum 14/12/2016. Ämnesområde Etologi

48. Fallahshahroudi, Amir. Domestication effects on the stress response in chickens. Genetics, physiology, and behaviour. Dissertation No. 1842. Datum 09/06/2017. Ämnesområde Etologi

49. Gudmundson, Sara. Species responses to environmental fluctuations. Impacts of food web interactions and noise color. Dissertation No. 1839. Datum 13/06/2017. Ämnesområde Teoretisk biologi

50. Zidar, Josefina. The relationship between personality and cognition in the fowl, Gallus gallus. Dissertation No. 1818. Datum 22/09/2017. Ämnesområde Etologi 
51. Sellman, Stefan. Quantifying risk in epidemiological and ecological contexts. Dissertation No. 1920. Datum 23/03/2018. Ämnesområde Teoretisk biologi

52. Tälle, Malin. Conservation of semi-natural grasslands. Effects of different management methods on biodiversity. Dissertation No. 1899. Datum 13/04/2018. Ämnesområde Biologi m inr ekologi

53. Lundström, Maria. Exploring fennoscandian agricultural history through genetic analysis of aged crop materials. Dissertation No. 1959. Datum 19/12/2018. Ämnesområde Biologi m inr genetik 


\section{FACULTY OF SCIENCE AND ENGINEERING}

Linköping Studies in Science and Technology, Dissertation No. 1989, 2019 Department of Physics, Chemistry, and Biology

Linköping University

SE-581 83 Linköping, Sweden

www.liu.se 